Pol. J. Food Nutr. Sci., 2020, Vol. 70, No. 3, pp. 275-289

DOI: $10.31883 /$ pjfns/122460 http://journal.pan.olsztyn.pl

Original research article

Food Quality and Functionality Section

\title{
Antioxidant and Renin-Angiotensin System Inhibitory Properties of Cashew Nut and Fluted-Pumpkin Protein Hydrolysates
}

\author{
Sunday A. Malomo ${ }^{1,2, *}$, Ifeanyi D. Nwachukwu ${ }^{1}$, Abraham T. Girgih ${ }^{1,3}$, \\ Atinuke O. Idowu ${ }^{4}$, Rotimi E. Aluko ${ }^{1}$, Tayo N. Fagbemi ${ }^{2,4}$
}

\author{
${ }^{l}$ Department of Food and Human Nutritional Sciences, University of Manitoba, Winnipeg R3T 2N2, Canada \\ ${ }^{2}$ Department of Food Science and Technology, Federal University of Technology, Akure, Nigeria \\ ${ }^{3}$ Department of Food Science and Technology, Federal University of Agriculture, Makurdi, Nigeria \\ ${ }^{4}$ Department of Food Science and Technology, Mountain Top University, Prayer City, Lagos, Nigeria
}

Key words: fluted pumpkin, cashew nut, protein hydrolysates, renin, angiotensin converting enzyme, antioxidant

Antioxidant and renin-angiotensin system (RAS)-inhibitory protein hydrolysates derived from the enzymatic hydrolysis of cashew nut (CNP) and fluted pumpkin (FPP) proteins were investigated. The CNP and FPP hydrolysates (CNPH and FPPH) from pepsin or Alcalase treatments were subjected to membrane ultrafiltration using different MWCOs to obtain $<1,1-3,3-5,5-10$, and $>10 \mathrm{kDa}$ peptide fractions. Hydrolysis of protein isolates at similar enzyme levels allowed obtaining peptic hydrolysates with a lower degree of hydrolysis (46.7-48.0\%) when compared to the Alcalase-produced hydrolysates (47.7-50.3\%). Amino acid composition revealed that CNPH had 28\% hydrophobic residues when compared to higher contents $(32-35 \%)$ in the 3-10 kDa peptide fractions. In contrast, aromatic residues increased from $8 \%$ in the FPPH to $9-13 \%$ in the peptide fractions. The in vitro ${ }^{\circ} \mathrm{OH}$ and $\mathrm{DPPH}^{\cdot}$ scavenging activities were significantly $(\mathrm{p}<0.05)$ enhanced by ultrafiltration but potency was inversely related to peptide size. The ferric-reducing power was the highest for the $<1 \mathrm{kDa}$ CNPH $(2.47)$ when compared to 1.33 for CNPH and other peptide fractions. Metal chelation ability was significantly $(\mathrm{p}<0.05)$ enhanced by ultrafiltration only for the CNPH with $21 \%$ compared to $~ 96 \%$ for the peptide fractions. ACE inhibition was significantly $(\mathrm{p}<0.05)$ lower for the Alcalase CNPH and peptide fractions $(\sim 87 \%)$ compared to $\sim 92 \%$ of pepsin-CNPH. However, renin inhibition was significantly $(\mathrm{p}<0.05)$ increased by ultrafiltration from 45.7 and $62.1 \%$ to $\sim 82.4$ and $96.5 \%$ for FPPH and CNPH, respectively. We conclude that the strong antioxidant properties coupled with RAS inhibition make CNPH and FPPH as well as their low molecular weight peptides potential ingredients to formulate health-promoting foods.

\section{INTRODUCTION}

Scientific research has focused heavily on evaluating the nutritional value of the underutilized and underexploited food crops. Crops like cashew nut [Liu et al., 2018], Buccholzia coriacea [Ijarotimi et al., 2018a], African yam bean [Ajibola et al., 2016], bambara groundnut [Thammarat et al., 2015] and fluted pumpkin seeds [Fagbemi, 2007] have been investigated as functional (foaming and emulsifying) ingredients in industrial applications based on their protein content (15$30 \%$ ). However, another option is to convert the proteins into value-added bioactive peptides by enzymatic hydrolysis. Bioactive peptides usually contain 2-20 amino acid residues per molecule, and are released upon enzymatic hydrolysis, during food processing or gastrointestinal digestion [Malomo et al., 2015]. These peptides may exert diverse physiological effects, such as antihypertensive, antimicrobial, antithrombotic, hypocholesterolaemic, antioxidative, and can also inhibit calmodulin-dependent enzymes [Aderinola et al., 2019; Nwa-

\footnotetext{
* Corresponding Author: Tel.: +234-813-019-0353;

E-mail: samalomo@futa.edu.ng (Dr. S.A. Malomo)
}

chukwu et al., 2019; Siddeeg et al., 2015; Thammarat et al., 2015]. These physiological effects are due to their amino acid composition, peptide sequences and molecular weights.

Fluted pumpkin (Telfairia occidentalis), commonly known as fluted gourd, Ugu and edikangikong (in Ibo and Efik, Nigeria languages, respectively) is a tropical plant grown in West Africa with its seeds widely consumed in Nigeria as soup condiments [Fagbemi, 2007]. The fermented seeds have high seed protein contents (66-71\%), which made them suitable functional ingredients to formulate marmalade and cookies [Fagbemi, 2007]. Cashew nut (Anarcadium occidentale) is a heart-like shaped fruit widely grown in Africa, with annual production of about 5-7 metric tonnes, but cultivated mainly as an export crop in Nigeria [Fagbemi, 2009]. Its proteins have a well-balanced amino acid composition, which is abundant enough to meet the requirements recommended by the FAO/WHO [Liu et al., 2018]. Besides, the SDS-PAGE pattern of cashew nut proteins revealed polypeptides of 21-32 and $53 \mathrm{kDa}$ molecular weights (MW) under reducing and non-reducing conditions [Liu et al., 2018]. The SDS-PAGE pattern under reducing conditions indicate presence of inter-molecular disulfide bonds in the polypeptide molecules [Liu et al., 2018; Malomo 
\& Aluko, 2015], which could lead to the production of sulfur-containing peptides with strong antioxidant properties. In addition, the amino acid compositions of fluted pumpkin and cashew nut proteins indicate an abundance of negatively charged amino acids (glutamic and aspartic) that can also contribute to antioxidant properties due to the presence of excess electrons [Udenigwe \& Aluko, 2011]. Fluted pumpkin and cashew nut proteins also contain high levels of positivelycharged (lysine and arginine) and branched-chain (valine, leucine, isoleucine) amino acids, which are reported to enhance the inhibitory activities of peptides against enzymes involved in hypertension development [Udenigwe et al., 2012; Wu et al., 2006a, b].

In disease pathogenesis and management systems, free radicals have been implicated to cause oxidative stress, giving rise to unacceptable state of health that reduce the quality of life through development of several chronic diseases. Therefore, it is important to inhibit or scavenge these radicals by using antioxidants [Arise et al., 2017]. Although, the body possesses natural self-defense mechanisms (such as antioxidants like glutathione and superoxide dismutase) to fight the free radicals, there exists a concern about the ineffective amounts present during illness and in old age [Thammarat et al., 2015]. Therefore, research efforts focused on food protein-derived hydrolysates, and peptides as new sources of natural antioxidants have recently emerged.

Various plant materials including Linum usitatissimum [Nwachukwu et al., 2019], Buccholzia coriacea [Ijarotimi et al., 2018b], Cajanus cajan [Olagunju et al., 2018], Moringa oleifera [Aderinola et al., 2019], Vigna subterranean [Arise et al., 2017], Cucumis melo [Siddeeg et al., 2015], and Voandzeia subterranea [Thammarat et al., 2015] have been identified as potential antioxidants sources. This was demonstrated by the strong antioxidant activity of their protein hydrolysates, including radical scavenging activity, reducing power and metal ion chelating activities.

Bioactive peptides from food proteins have also exhibited renin-angiotensin system (RAS)-inhibitory activity. Regulation of arterial blood pressure in the human body is mainly achieved through diverse physiological systems [Majumder \& Wu, 2015] including the RAS, kinin-nitric oxide system (KNOS), renin-chymase system (RCS) and neutral endopeptidase system (NEPS). The key elements constituting the RAS are both the renin and angiotensin converting enzyme (ACE). The renal renin acts on the zymogen, angiotensinogen from the liver to produce inactive decapeptide, angiotensin-I (ATI). ACE then, hydrolyzes AT-I by the removal of the dipeptide His-Leu from the C-terminus, to produce angiotensin-II (AT-II), a potent vasoconstrictor octapeptide [Aluko, 2019a; Malomo et al., 2015]. High levels of AT-II can lead to excessive vasoconstriction, which causes hypertension, a chronic medical symptom responsible for worldwide health problems because of its ability to trigger cardiovascular complications including peripheral vascular disease and renal dysfunctions [Arise et al., 2017]. Thus, RAS inhibitors block the formation of AT-II and potentiate action of the vasodilatory nitric oxide [Malomo et al., 2015].

Several potent synthetic ACE inhibitors (captopril, lisinopril, fosinopril, enalapril) are used extensively in the clinical treatment of hypertension but with significant adverse effects (dry cough, skin rashes, headache) on health [Malomo et al., 2015]. Recent studies on diverse peptides released from pigeon pea [Olagunju et al., 2018], Bambara groundnut [Arise et al., 2017], and pistachio [Li et al., 2014] proteins have shown ability to modulate RAS functions. Interestingly, studies on food bioactive peptides do not indicate side effects in the hypertension rat model [Udenigwe et al., 2017; Girgih et al., 2016]. However, previous works have reported on some structural features of potent antioxidant as well as ACE and renin-inhibitory peptides. For example, a quantitative structure-activity relationship (QSAR) study was used to show that amino acids with bulky and hydrophobic side groups are preferred for ACE-inhibitory dipeptides [Wu et al., 2006a]. For tripeptides, an aromatic amino acid at the $\mathrm{C}$-terminus with a positively charged amino acid in the middle and a hydrophobic residue at the N-terminus enhanced ACE inhibition. For longer peptides, the ACE-inhibitory activity was dependent on the four amino acid residues present at the $\mathrm{C}$-terminus $[\mathrm{Wu}$ et al., 2006b]. Meanwhile, the potency of dipeptides that inhibit renin activity was shown to be dependent on a branched-chain amino acid at the N-terminus with tryptophan at the C-terminus [Udenigwe et al., 2012]. With respect to antioxidant protein hydrolysates, the presence of sulfur-containing, acidic amino acids, lysine and leucine enhanced free radical scavenging ability [Udenigwe \& Aluko, 2011].

Accordingly, more studies are now directed towards understanding how to produce food protein-derived peptides to be used as nutraceuticals for managing chronic diseases. This study, thus aimed to investigate and assess the feasibility of producing enzymatic fluted pumpkin seed and cashew nut protein hydrolysates with in vitro antioxidant and RAS-inhibitory activities.

\section{MATERIALS AND METHODS}

\section{Materials}

Fluted pumpkin seeds and cashew nuts were obtained from the Federal University of Technology, Teaching and Research Farm, Akure, Nigeria, authenticated in the Department of Crop, Soil and Pest Management, Federal University of Technology, Akure, Nigeria. Renin was purchased from Cayman Chemical Co. (Ann Arbor, MI, USA) while other enzymes such as Alcalase, pepsin and ACE (rabbit lung) were purchased from Sigma-Aldrich (St. Louis, MO, USA). Other analytical-grade reagents were obtained from Fisher Scientific (Oakville, ON, Canada).

\section{Preparation of fluted pumpkin and cashew nuts protein meal}

The fluted pumpkin seeds were dehulled and sliced into small pieces according to the previously described method [Fagbemi, 2007]. The sliced seeds were oven dried at $50^{\circ} \mathrm{C}$ (Plus11 Sanyo Gallenkamp PLC, UK), for $8 \mathrm{~h}$ and then pulverized into flour using a coffee grinder. The flour was then defatted continuously for $8 \mathrm{~h}$ with a Soxhlet's apparatus using $n$-hexane as a solvent and air-dried for $24 \mathrm{~h}$ in a fume hood at room temperature to remove solvent residues. The defatted 
flour was then passed through $0.5 \mathrm{~mm}$ sieves, packed in plastic containers, labeled as the fluted pumpkin protein flour (FPP), and kept at $-20^{\circ} \mathrm{C}$.

The cashew nuts were cut into halves using the manual cashew kernel cutter according to the previously described method [Fagbemi, 2009]. After cutting, the nuts were removed and dried in an oven at $100^{\circ} \mathrm{C}$ for $2 \mathrm{~h}$. The covering testas were removed by squeezing and then winnowed to obtain cream color nuts. The nuts were then broken into smaller pieces and defatted using $n$-hexane solvent. The defatted nuts were air-dried for $24 \mathrm{~h}$ in a fume hood at room temperature to remove the residual $n$-hexane, and thereafter milled into flour using a blender (Philips laboratory blender, HR2811 model, The Netherlands). The defatted cashew nut flour (CNP) was passed through a sieve with $0.5 \mathrm{~mm}$ mesh size, packed into a polythene bag and then stored at $-20^{\circ} \mathrm{C}$.

\section{Preparation of fluted pumpkin seed and cashew nuts protein isolates}

Fluted pumpkin seed and cashew nuts protein isolates (FPPI and CNPI) were produced from FPP and CNP according to the method described by Malomo et al. [2014] with slight modifications. Briefly, FPP and CNP were dispersed in deionized water $(1: 20, w / v)$ and the dispersion was adjusted to $\mathrm{pH} 10$ using $2 \mathrm{M} \mathrm{NaOH}$ to solubilize the proteins while stirring at $37^{\circ} \mathrm{C}$ for $2 \mathrm{~h}$; this was followed by centrifugation $\left(7,000 \times g, 60 \mathrm{~min}\right.$ at $\left.4^{\circ} \mathrm{C}\right)$. The precipitate was discarded while the supernatant was filtered and thereafter adjusted to $\mathrm{pH} 4.0$ with $2 \mathrm{M} \mathrm{HCl}$ to precipitate the proteins; this was followed by centrifugation $\left(7,000 \times g, 60 \mathrm{~min}\right.$ at $\left.4^{\circ} \mathrm{C}\right)$. The resultant precipitate was re-dispersed in deionized water, adjusted to $\mathrm{pH} 7.0$ with $2 \mathrm{M} \mathrm{NaOH}$, and freeze-dried to obtain the FPPI and CNPI. Protein contents were determined by the Lowry method [Markwell et al., 1978] using $0.1 \mathrm{M}$ $\mathrm{NaOH}$ to dissolve the samples.

\section{Preparation of fluted pumpkin and cashew nuts protein hydrolysates and ultrafiltration membrane hydrolysate fractions}

Fluted pumpkin seeds and cashew nut protein hydrolysates (FPPH and CNPH) were produced according to the method described by Malomo et al. [2015] with slight modifications using Alcalase at $50^{\circ} \mathrm{C}, \mathrm{pH} 8$ for $4 \mathrm{~h}$ and pepsin at $37^{\circ} \mathrm{C}, \mathrm{pH} 2$ for $2 \mathrm{~h}$. FPPI and CNPI (5\%, w/v, protein weight basis) were each suspended in deionized water in a glass beaker equipped with a stirrer, and adjusted to the appropriate temperature and $\mathrm{pH}$ prior to addition of the proteolytic enzyme. Alcalase $(>2.4 \mathrm{U} / \mathrm{g}$ ) and pepsin ( $>250$ units $/ \mathrm{mg}$ ) were added separately to the FPPI and CNPI slurry at a 1-4:100 ratio (E/S). During hydrolysis, the required $\mathrm{pH}$ was maintained constant by addition of $\mathrm{NaOH}$ and $\mathrm{HCl}$, respectively after which the enzymes were inactivated by adjusting to $\mathrm{pH} 4.0$ with $2 \mathrm{M} \mathrm{HCl}$ followed by immersing the reaction vessel in boiling water bath for $10 \mathrm{~min}$. After cooling to room temperature, the undigested proteins were precipitated by centrifugation $(3,500 \times g, 60 \mathrm{~min}$ at $4{ }^{\circ} \mathrm{C}$ ) and a portion of each supernatant was freeze-dried as the FPPH and $\mathrm{CNPH}$, which were then stored at $-20^{\circ} \mathrm{C}$. Protein contents of the freeze-dried FPPH and CNPH were determined using the modified Lowry method [Markwell et al.,
1978]. The supernatants from Alcalase-produced FPPH and pepsin-produced $\mathrm{CNPH}$ at 2:100 and 3:100 ratios (E/S), respectively were also sequentially passed through ultrafiltration membranes with molecular weight cut-off (MWCO) of $1,3,5$, and $10 \mathrm{kDa}$ in an Amicon stirred ultrafiltration cell (Merck KGaA, Darmstadt, Germany). Thus, the retentate from $1 \mathrm{kDa}$ membrane was passed through $3 \mathrm{kDa}$ membrane whose retentate was passed through $5 \mathrm{kDa}$ and the last retentate was then passed through $10 \mathrm{kDa}$ membrane. The permeate from each MWCO membrane was collected as peptide sizes of $<1,1-3,3-5$, and 5-10 kDa, freeze-dried, and stored at $-20^{\circ} \mathrm{C}$.

\section{Amino acid composition analysis}

The amino acid profiles of the fluted pumpkin and cashew seed protein products were determined using the HPLC Pico-Tag system (Waters, Milford, MA, USA) according to the previously described method after samples were digested with $6 \mathrm{M} \mathrm{HCl}$ for $24 \mathrm{~h}$ [Bidlingmeyer et al., 1984]. The cysteine and methionine contents were determined after performic acid oxidation [Gehrke et al., 1985] and the tryptophan content was determined after alkaline hydrolysis [Landry \& Delhaye, 1992]. The samples were derivatized for 20 min using a solvent mixture containing 95\% ethanol:water:triethylamine:phenylisothiocyanate $(7: 1: 1: 1, v / v / v / v)$, dried under vacuum and dissolved in buffer A $(940 \mathrm{~mL}$ of $0.14 \mathrm{M}$ sodium acetate, $\mathrm{pH}$ 6.40, containing $0.05 \%$ triethylamine, mixed with $60 \mathrm{~mL}$ acetonitrile) prior to HPLC separation on the Pico-Tag column using a flow rate of $0.45 \mathrm{~mL} / \mathrm{min}$ and detection at $254 \mathrm{~nm}$. The gradient was from 10-50\% buffer B (60\% acetonitrile and $40 \%$ water by volume) in buffer A over $10 \mathrm{~min}$.

\section{Determination of the degree of hydrolysis}

The degree of hydrolysis (DH) was defined as percentage of $\alpha$-amino groups of substrates released during hydrolysis and was determined using the trinitrobenzene sulfonic acid (TNBS) method as previously described [Adler-Nissen, 1979] and modified by Malomo et al. [2015]. Briefly, CNPI and FPPI were treated under vacuum with $6 \mathrm{M} \mathrm{HCl}$ for $24 \mathrm{~h}$ and $\alpha$-total amino groups as L-leucine equivalent was determined. The DH was calculated as the percentage ratio of the L-leucine equivalent of CNPH and FPPH to that of CNPI and FPPI.

\section{Hydroxyl radical scavenging assay}

The hydroxyl radical scavenging activities of FPPH, $\mathrm{CNPH}$, and peptide fractions were determined according to the method described by Girgih et al. [2011]. Experimental samples, GSH and 1,10-phenanthroline $(3 \mathrm{mM})$ were each separately dissolved in $0.1 \mathrm{M}$ phosphate buffer ( $\mathrm{pH}$ 7.4) while $\mathrm{FeSO}_{4}(3.0 \mathrm{mM})$ and $0.01 \%$ hydrogen peroxide were each dissolved in distilled water. An aliquot $(50 \mu \mathrm{L})$ of samples or GSH (reaction mixture concentration of $1 \mathrm{mg} / \mathrm{mL}$ ) or buffer (blank) was first added to a clear, flat bottom 96-well plate followed by $50 \mu \mathrm{L}$ of 1,10-phenanthroline and then $50 \mu \mathrm{L}$ of $\mathrm{FeSO}_{4}$. To initiate the Fenton reaction in the wells, $50 \mu \mathrm{L}$ of hydrogen peroxide was added to the mixture, the plate was covered and incubated at $37^{\circ} \mathrm{C}$ for $1 \mathrm{~h}$ with shaking. The change in absorbance values of samples (s) and blank (b) 
were measured using Biotex 542 Powerwave XS microplatereader (Biotek Instruments Inc., Winooski, Vermont, USA) at $536 \mathrm{~nm}$ at $10 \mathrm{~min}$ intervals for $1 \mathrm{~h}$. The hydroxyl radical scavenging activity was calculated using the reaction rate $(\Delta \mathrm{A} /$ min) equation below:

$\mathrm{OH}$ radical scavenging activity $(\%)=$

$$
=\left(\frac{\left(\Delta \mathrm{A}_{536} / \mathrm{min}\right) \mathrm{b}-\left(\left(\Delta \mathrm{A}_{536} / \mathrm{min}\right) \mathrm{s}\right.}{\left(\Delta \mathrm{A}_{536} / \mathrm{min}\right) \mathrm{b}}\right) \times 100
$$

\section{2,2-Diphenyl-1-picryhydrazyl radical scavenging assay}

The scavenging effect of CNPH, FPPH, and their peptide fractions on 2,2-diphenyl-1-picryhydrazyl free radical (DPPH*) was measured according to the method of Aluko \& Monu [2003]. FPPH, CNPH and peptide fractions (10 mg) were each dissolved in $1 \mathrm{~mL}$ of buffer $(0.1 \mathrm{M}$ sodium phosphate buffer, $\mathrm{pH} 7.0$ containing $1 \%(w / v)$ Triton X-100). $\mathrm{DPPH}^{\bullet}$ was dissolved in methanol to a final concentration of $100 \mu \mathrm{M}$. A $100 \mu \mathrm{L}$ aliquot of each sample solution (containing FPPH, CNPH or peptide fractions) was mixed with $100 \mu \mathrm{L}$ of the $\mathrm{DPPH}^{*}$ solution in the 96 -well plate to a reaction mixture concentration of $1 \mathrm{mg} / \mathrm{mL}(0.2 \mathrm{mg} / 200 \mu \mathrm{L})$ and incubated at room temperature in the dark for $30 \mathrm{~min}$. The absorbance values of the blank, reduced glutathione (GSH) and samples were measured at $517 \mathrm{~nm}$ using a Biotex 542 Powerwave XS microplate-reader. The blank consisted of sodium phosphate buffer in place of the peptide sample, while GSH (1 mg/mL) was used as the positive control. The percent $\mathrm{DPPH}^{\bullet}$ radical scavenging activity of the samples was determined using the following equation:

DPPH'radical scavenging activity $(\%)=\left(1-\frac{A_{517} \text { of sample }}{A_{517} \text { of blank }}\right) \times 100$

\section{Ferric-reducing power}

The ferric-reducing power of the FPPH, CNPH, and membrane fractions was determined according to the modified method of Zhang et al. [2008]. Experimental sample or GSH $(10 \mathrm{mg}$ ) was dissolved in $1 \mathrm{~mL}$ of $0.2 \mathrm{M}$ phosphate buffer, $\mathrm{pH}$ 6.6; an aliquot $(250 \mu \mathrm{L})$ was mixed with $250 \mu \mathrm{L}$ of the buffer and $250 \mu \mathrm{L}$ of $1 \%$ potassium ferricyanide solution. The mixture was thoroughly mixed using a vortex machine and heated at $50^{\circ} \mathrm{C}$ for $20 \mathrm{~min}$. After incubation, $250 \mu \mathrm{L}$ of $10 \%$ trichloroacetic acid was added followed by $50 \mu \mathrm{L}$ of $0.1 \%$ ferric chloride dissolved in double distilled water and then $200 \mu \mathrm{L}$ of double distilled water was added to give sample concentration of $1 \mathrm{mg} / \mathrm{mL}$ reaction mixture. The solution was allowed to stand for $10 \mathrm{~min}$ at room temperature, after which it was centrifuged at $1,000 \times g$ for $10 \mathrm{~min}$. An aliquot $(200 \mu \mathrm{L})$ of the supernatant was transferred to a clear bottom 96-well plate and the absorbance was measured at $700 \mathrm{~nm}$ using a Biotex 542 Powerwave XS microplate reader. The ferric reducing power was presented as absorbance values at $700 \mathrm{~nm}$.

\section{Chelation of ferrous ions}

The ferrous ion chelating activity of the FPPH, CNPH, and membrane fractions was determined using a modified method of Xie et al. [2008]. Experimental samples and GSH solution were each combined with $0.05 \mathrm{~mL}$ of $2 \mathrm{mM}$ $\mathrm{FeCl}_{2}$ and $1.85 \mathrm{~mL}$ double distilled water in a reaction tube to give $1 \mathrm{mg} / \mathrm{mL}$ reaction mixture concentration. Ferrozine solution $(0.1 \mathrm{~mL}$ of $5 \mathrm{mM})$ was added and mixed thoroughly. The mixture was then allowed to stand at room temperature for $10 \mathrm{~min}$ from which an aliquot of $200 \mu \mathrm{L}$ was removed and added to a clear bottom 96-well plate. A blank experiment was also conducted by replacing the sample with $1 \mathrm{~mL}$ of double distilled water. The absorbance of blank and sample at $562 \mathrm{~nm}$ was measured using a Biotek microplate reader and the ferrous ion chelating activity of the sample compared to that of GSH. The percentage chelating effect (\%) was calculated using the following equation:

Ferrous ion chelating activity $(\%)=\left(1-\frac{A_{562} \text { of sample }}{A_{562} \text { of blank }}\right) \times 100$

\section{Angiotensin-Converting Enzyme (ACE) inhibition assay}

The ability of FPPH, CNPH, and membrane fractions to inhibit in vitro ACE activity was measured according to a spectrophotometric method using synthetic $N$-[3-(2-furyl) acryloyl]-1-phenylalanyl-glycyl-glycine (FAPGG) as the substrate (Sigma-Aldrich, St. Louis, MO, USA) as reported by Malomo et al. [2015]. Briefly, $1 \mathrm{~mL}$ of $0.5 \mathrm{mM}$ FAPGG (dissolved in $50 \mathrm{mM}$ Tris- $\mathrm{HCl}$ buffer containing $0.3 \mathrm{M} \mathrm{NaCl}$, $\mathrm{pH}$ 7.5) was mixed with $20 \mu \mathrm{L}$ of ACE (20 mU final reaction activity) and $200 \mu \mathrm{L}$ sample dissolved in same buffer. The rate of decrease in absorbance at $345 \mathrm{~nm}$ was recorded for $2 \mathrm{~min}$ at room temperature using Varian Cary 50-UV/Visible spectrophotometer (Varian Inc., Belrose, NSW, Australia). The buffer was used instead of sample solutions in the blank experiment, while the sample concentration in the reaction mixture was $1 \mathrm{mg} / \mathrm{mL}$. ACE activity was expressed as the rate of reaction $(\triangle \mathrm{A} / \mathrm{min})$ and inhibitory activity was calculated as:

ACE inhibition $(\%)=1-(\Delta \mathrm{A} / \mathrm{min}-1($ sample $) / \Delta \mathrm{A} / \mathrm{min}-1$ (blank $)) \times 100$

where: $\Delta \mathrm{A} / \mathrm{min}_{\text {(sample) }}$ and $\Delta \mathrm{A} / \mathrm{min}_{\text {(blank) }}$ represent ACE activity in the presence and absence of the samples, respectively.

\section{Renin inhibition assay}

In vitro inhibition of human recombinant renin activity by FPPH, CNPH, and membrane fractions was conducted using the Renin Inhibitor Screening Assay Kit (Cayman Chemical Co., Ann Arbor, MI, USA) according to the previously described method [Malomo et al., 2015]. Prior to the assay, renin buffer was diluted in $50 \mathrm{mM}$ Tris- $\mathrm{HCl}, \mathrm{pH} 8.0$, containing $100 \mathrm{mM} \mathrm{NaCl}$. The renin protein solution was diluted 20 times with the assay buffer before use and pre-warmed to $37^{\circ} \mathrm{C}$ prior to initiating the reaction in a fluorometric microplate reader (Spectra MAX Gemini, Molecular Devices, Sunnyvale, CA, USA) maintained at $37^{\circ} \mathrm{C}$. Before the reaction, (i) $20 \mu \mathrm{L}$ substrate, $160 \mu \mathrm{L}$ assay buffer, and $10 \mu \mathrm{L}$ Milli-Q water were added to the background wells; (ii) $20 \mu \mathrm{L}$ substrate, $150 \mu \mathrm{L}$ assay buffer, and $10 \mu \mathrm{L}$ Milli-Q water were added to the blank wells; and (iii) $20 \mu \mathrm{L}$ substrate, $150 \mu \mathrm{L}$ assay buffer, and $10 \mu \mathrm{L}$ sample $(1 \mathrm{mg} / \mathrm{mL}$ reaction mixture concentration) were added to the inhibitor wells. The reaction was initiated by adding $10 \mu \mathrm{L}$ renin to the blank and sample wells. The microplate was shaken for $10 \mathrm{~s}$ to mix, incubated at $37^{\circ} \mathrm{C}$ for $15 \mathrm{~min}$, and the fluorescence intensity (FI) 
was recorded using excitation and emission wavelengths of 340 and $490 \mathrm{~nm}$, respectively. The percentage renin inhibition was calculated as follows:

$$
\text { Renin inhibition }(\%)=1-(\text { FI sample }) / \text { FI }(\text { control })) \times 100
$$

\section{Statistical analysis}

Triplicate replications were used to obtain mean values and standard deviations. Statistical analysis was performed with SAS (Statistical Analysis Software 9.1) using one-way ANOVA. Duncan's multiple-range test was carried out to compare the mean values for samples with significant differences taken at $\mathrm{p}<0.05$.

\section{RESULTS AND DISCUSSION}

\section{Amino acid composition}

The protein contents of the CNPI and FPPI are 84 and $82.6 \%$, respectively, which fall in the ranges (80-90\%) previously reported [Malomo et al., 2014] for protein isolates from different plant protein sources. The amino acid composi- tions of peptides present in CNPH and FPPH as well as their membrane fractions are presented in Table 1. The results clearly showed that Glu, Asp, and Arg were present in the highest amounts of 14.66-23.29, 8.71-11.24, and 5.94-20.89 g/100 g, when compared to $3.32-7.15,3.20-5.00$, and $1.40-2.85 \mathrm{~g} / 100 \mathrm{~g}$ obtained for other amino acids such as Val, Ile and Trp, respectively. The potentials of Glu and Asp to donate excessive electrons as free radicals scavengers (strong antioxidant) and Arg to work as NO-precursor, a known vasodilator, made them potential tissue protective agents against oxidative stress [Jakubczyk \& Baraniak, 2014] and hypertension [Malomo et al., 2015]. Similar levels of Val, Ile, Glu, and Arg have been previously reported for cashew nut albumin and globulin fractions [Liu et al., 2018]. In this study, the results (3.27-6.25 g/100 g) obtained for Pro, a crucial amino acid that has been reported to contribute to the effectiveness of ACE-inhibitory peptides, were higher than the 1.33-2.25 g/100 g reported for Phaseolus lunatus protein hydrolysates [Magana et al., 2015]. The results (Table 1) further confirm the protein hydrolysates as rich sources of hydrophobic (HAA) and aromatic (AAA) amino acids that could contribute to the antioxidant and RAS inhibition activities [Magana et al., 2015].

TABLE 1. Amino acid composition (g/100 g) of cashew nut (CNPH) and fluted-pumpkin (FPPH) protein hydrolysates and their membrane fractions.

\begin{tabular}{|c|c|c|c|c|c|c|c|c|c|c|c|}
\hline \multirow{2}{*}{$\begin{array}{c}\text { Amino } \\
\text { acid }\end{array}$} & \multirow{2}{*}{$\mathrm{CNPH}^{1}$} & \multicolumn{4}{|c|}{ CNPH fractions } & \multirow{2}{*}{$\mathrm{FPPH}^{2}$} & \multicolumn{4}{|c|}{ FPPH fractions } & \multirow{2}{*}{$\begin{array}{c}\text { Least } \\
\text { significant } \\
\text { difference } \\
(\mathrm{p}<0.05)\end{array}$} \\
\hline & & $<1 \mathrm{kDa}$ & $1-3 \mathrm{kDa}$ & $3-5 \mathrm{kDa}$ & $5-10 \mathrm{kDa}$ & & $<1 \mathrm{kDa}$ & $1-3 \mathrm{kDa}$ & $3-5 \mathrm{kDa}$ & $5-10 \mathrm{kDa}$ & \\
\hline Asp & 11.24 & 9.10 & 9.61 & 10.05 & 11.12 & 8.71 & 10.81 & 10.62 & 9.15 & 11.03 & 0.97 \\
\hline Thr & 3.38 & 3.14 & 3.37 & 4.41 & 3.91 & 2.71 & 3.54 & 3.59 & 3.86 & 3.29 & 0.03 \\
\hline Ser & 4.93 & 5.37 & 4.96 & 5.02 & 4.99 & 4.23 & 5.25 & 5.74 & 6.15 & 4.88 & 0.87 \\
\hline Glu & 18.56 & 23.29 & 18.39 & 18.63 & 21.42 & 18.86 & 21.15 & 20.15 & 14.66 & 18.94 & 3.42 \\
\hline Pro & 5.18 & 4.12 & 4.55 & 3.73 & 4.38 & 6.25 & 4.69 & 4.89 & 3.27 & 4.94 & 0.77 \\
\hline Gly & 4.46 & 4.21 & 4.53 & 3.68 & 4.36 & 4.90 & 4.50 & 4.42 & 4.17 & 4.40 & 0.84 \\
\hline Ala & 4.27 & 2.98 & 4.30 & 4.85 & 3.94 & 3.14 & 3.68 & 3.41 & 6.44 & 4.18 & 0.06 \\
\hline Cys & 0.82 & 1.95 & 0.83 & 0.40 & 0.40 & 0.99 & 0.88 & 1.05 & 0.21 & 0.87 & 0.11 \\
\hline Val & 4.25 & 5.10 & 4.57 & 7.04 & 7.15 & 3.32 & 6.07 & 5.16 & 5.97 & 4.48 & 0.88 \\
\hline Met & 1.37 & 1.25 & 1.43 & 1.38 & 1.43 & 1.05 & 1.49 & 1.27 & 1.94 & 1.41 & 0.12 \\
\hline Ile & 4.24 & 3.63 & 4.29 & 4.50 & 4.02 & 3.20 & 3.75 & 3.64 & 5.00 & 4.33 & 0.10 \\
\hline Leu & 7.90 & 7.03 & 7.74 & 13.56 & 10.84 & 6.12 & 8.76 & 7.26 & 10.32 & 7.96 & 1.24 \\
\hline Tyr & 4.01 & 3.19 & 3.88 & 3.14 & 3.38 & 3.45 & 3.64 & 3.27 & 5.00 & 3.78 & 0.08 \\
\hline Phe & 4.56 & 4.51 & 4.65 & 6.64 & 5.09 & 3.10 & 4.58 & 4.16 & 6.02 & 4.33 & 0.29 \\
\hline His & 2.67 & 2.39 & 2.77 & 1.78 & 2.01 & 3.16 & 2.49 & 2.78 & 2.72 & 2.71 & 0.12 \\
\hline Lys & 3.20 & 3.96 & 3.25 & 2.43 & 2.64 & 4.41 & 3.23 & 4.41 & 2.57 & 3.03 & 0.14 \\
\hline $\operatorname{Arg}$ & 13.35 & 13.44 & 15.23 & 5.94 & 7.10 & 20.89 & 9.45 & 12.28 & 10.79 & 13.90 & 4.21 \\
\hline Trp & 1.62 & 1.40 & 1.73 & 2.85 & 1.84 & 1.52 & 2.08 & 1.91 & 1.78 & 1.57 & 0.08 \\
\hline $\mathrm{HAA}^{3}$ & 28.03 & 26.06 & 27.71 & 35.46 & 32.16 & 24.07 & 29.32 & 26.68 & 33.15 & 28.17 & 6.20 \\
\hline $\mathrm{AAA}^{4}$ & 10.19 & 9.10 & 10.26 & 12.63 & 10.31 & 8.07 & 10.30 & 9.34 & 12.80 & 9.68 & 0.94 \\
\hline
\end{tabular}

${ }^{1} \mathrm{HAA}=$ Hydrophobic amino acids, ${ }^{2} \mathrm{AAA}=$ Aromatic amino acids. 


\section{Degree of hydrolysis}

The bioavailability of peptides released during protein hydrolysis process is related to their structural properties (amino acid composition and sequence), which is dependent on the degree of hydrolysis [Jakubczyk \& Baraniak, 2014]. Figure 1 revealed the different degrees of hydrolysis (DH) for the enzymatic treatment of CNPI and FPPI proteins. The CNPI was observed to be more readily hydrolyzed by Alcalase at enzyme to substrate $(\mathrm{E} / \mathrm{S})$ ratios of $1-3: 100$ than the FPPI, which may be due to differences in the primary structure of the two seed proteins. In contrast, similar DH values were obtained for CNPI and FPPI hydrolyzed by pepsin. Generally, for each seed protein, higher DH values were achieved for hydrolysates obtained with Alcalase when compared to pepsin activities. The current outcome is contrary to the findings of Arise et al. [2019] where the DH of Azadirachta indica seed protein hydrolysates from pepsin activity was higher $(27.88 \%)$ than the $14.73 \%$ obtained for Alcalase hydrolysis. The higher DH observed for the Alcalase-produced hydrolysates $(\sim 51 \%)$ might be due to the broad and nonspecific enzymatic activity when compared to pepsin (47\%), which has a narrow proteolytic specificity for peptide bonds formed by amino acids with aromatic or bulky side chains [Aluko, 2019b]. The results are comparable to the $45 \% \mathrm{DH}$ reported for Alcalase-hydrolyzed horse gram flour [Bhaskar et al., 2019]. Decreases in DH with increased E:S may be due to enzyme overcrowding, which could lead to redundancy or antagonistic effects that lowered the rate of proteolysis.

The DH values presented for peptic CNPH (47\%) and FPPH (46\%) were higher than the values of $14, \sim 28$, and $28 \%$ previously reported for hydrolysates obtained by simulated gastrointestinal digestion of pea globulin [Jakubczyk \& Baraniak, 2014], neem seed protein [Arise et al., 2019], and hemp protein [Malomo et al., 2015], all with ACE-inhibitory or RAS-inhibitory activities. The samples preparation, different protein sources, and specificities of the proteases [Jakubczyk \& Baraniak, 2014] might have resulted in the differences of $\mathrm{DH}$ values obtained for these hydrolysates. The high DH for CNPH and FPPH indicates short peptide lengths, which could enhance inhibition of ACE and renin activities. Overall, the data showed that the CNPI and FPPI were highly susceptible to Alcalase and pepsin proteolysis.

\section{Hydroxyl radical scavenging activity}

The hydroxyl radical $\left({ }^{\circ} \mathrm{OH}\right)$ is one of the most damaging reactive oxygen species (ROS) because it reacts with all cellular macromolecules such as proteins, polyunsaturated fatty acids (PUFAs) and nucleic acids to induce severe damages to cells [Jin et al., 2016]. Therefore, 'OH scavenging is an effective defense strategy of the human body against various diseases elicited by ROS [Zhuang et al., 2013]. The ability of CNPH or FPPH and their membrane fractions to scavenge ${ }^{\circ} \mathrm{OH}$ is presented in Figure 2. The ${ }^{\circ} \mathrm{OH}$ scavenging activity (HRSA) of $\mathrm{CNPH}$ and $\mathrm{FPPH}$ were 58 and $38 \%$, respectively when compared to GSH (57\%), a recognized potent physiological antioxidant. However, the HRSA was significantly $(\mathrm{p}<0.05)$ increased upon membrane filtration and separation into peptides of varying sizes. The results further showed the direct and indirect relationship between the DH (Figure 1) and mo-

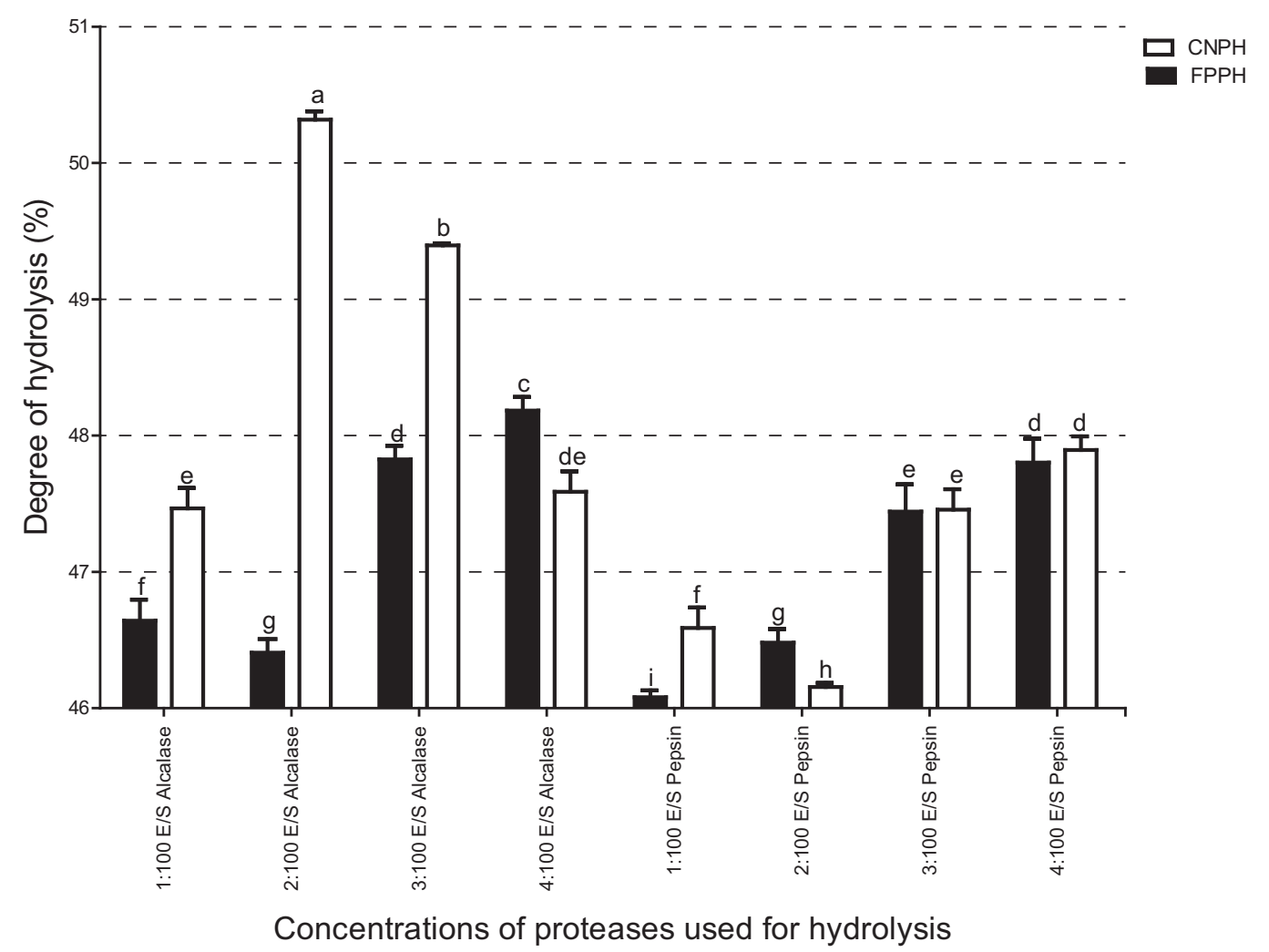

FIGURE 1. Degree of hydrolysis of cashew nut (CNPH) and fluted-pumpkin (FPPH) proteins at different protease concentrations (1-4:100 ratio E/S). 
lecular weight sizes, respectively on the HRSA of the protein hydrolysates. For instance, the higher DH of CNPH over FPPH was directly related to their HRSA while the scavenging effect reduced with increase in peptide size. For example, the HRSA values of $<1 \mathrm{kDa}$ fractions of $\mathrm{CNPH}(\sim 99 \%)$ and FPPH $(95 \%)$ were higher than those of the $>10 \mathrm{kDa}$ fractions (42 and 38\%, respectively). In addition, the CNPH had a higher content of HAA, which may have contributed to the higher HRSA when compared to FPPH.

Previous report [Ketnawa et al., 2017] had suggested that the antioxidant activity of peptides is dependent on the molecular mass, hydrophobicity and type of amino acid as well as enzymatic hydrolysis reaction conditions. The current findings (Figure 2) are in agreement with the stronger HRSA for LMW than the HMW peptides of barley glutelin [Xia et al., 2012] but are different from the reported trend for B. coriacea-derived peptides [Ijarotimi et al., 2018b]. Our results are higher than the 23.36, 22.50, 32.3, and 81\% HRSA reported for pancreatin-produced pigeon pea [Olagunju et al., 2018], black soybean [Ralison et al., 2013], 5-10 kDa fractions from B. coriacea seed [Ijarotimi et al., 2018b], and alfalfa leaf [Xie et al., 2008] protein hydrolysates, respectively.

\section{2,2-Diphenyl-1-picryhydrazyl radical scavenging activity}

2,2-Diphenyl-1-picryhydrazyl radical scavenging activity (DRSA) is one of the many assays employed to understand the mechanism of antioxidant action of food protein-derived peptides. Figure 3 showed the DRSA of the pepsin-produced (3:100 ratio $\mathrm{E} / \mathrm{S}$ ) $\mathrm{CNPH}$ and Alcalase-produced (2:100 ratio $\mathrm{E} / \mathrm{S}) \mathrm{FPPH}$, which ranged from 40 to $57 \%$ when compared to $60 \%$ for GSH, a recognized potent physiological antioxidant. Meanwhile, a slightly higher DRSA (41-98\%) was observed after the protein hydrolysates were fractionated by ultrafiltra- tion. The improved ability of $<1 \mathrm{kDa}$ peptides to scavenge free radicals with maximum efficiency when compared to HMW peptides have been suggested from previous findings on antioxidative potentials of Parkia speciosa [Siow \& Gan, 2013] and hemp seed [Malomo et al., 2015] protein hydrolysates. In addition, the small-size LMW $(<1 \mathrm{kDa})$ peptides may be resistant to endopeptidase degradation in the digestive tract and enhance faster absorption from the gastrointestinal tract into blood circulation, which could promote ability to interact with and scavenge endogenous free radicals [Erdmann et al., 2008].

The DRSA values of our peptide fractions (98\%) are better than the 32, 56.22, and 53.15\% reported for the Alcalase-produced hydrolysates of asparagus extract [Montone et al., 2019], seinat seed protein albumin, and globulin [Siddeeg et al., 2015], respectively. The reason for this might be that CNPH and FPPH peptide fractions probably had higher DPPH affinity and H-atom donating capacity when compared to those of asparagus extract and seinat seed protein fractions since DPPH assay involved a reduction mechanism by active compounds [Siddeeg et al., 2015]. The high levels of acidic and hydrophobic amino acids may have contributed to the strong DRSA of the protein hydrolysates [Udenigwe \& Aluko, 2011].

\section{Ferric reducing power}

A reducing power is an effective method for assessing the ability of an antioxidant in electron donation mechanism. Figure 4 shows the reducing power (absorbance) of CNPH, FPPH and their membrane fractions measured at $700 \mathrm{~nm}$. It is noteworthy that an increase in absorbance indicates better reducing power of the test protein sample. The CNPH and its membrane fractions, with the excep-

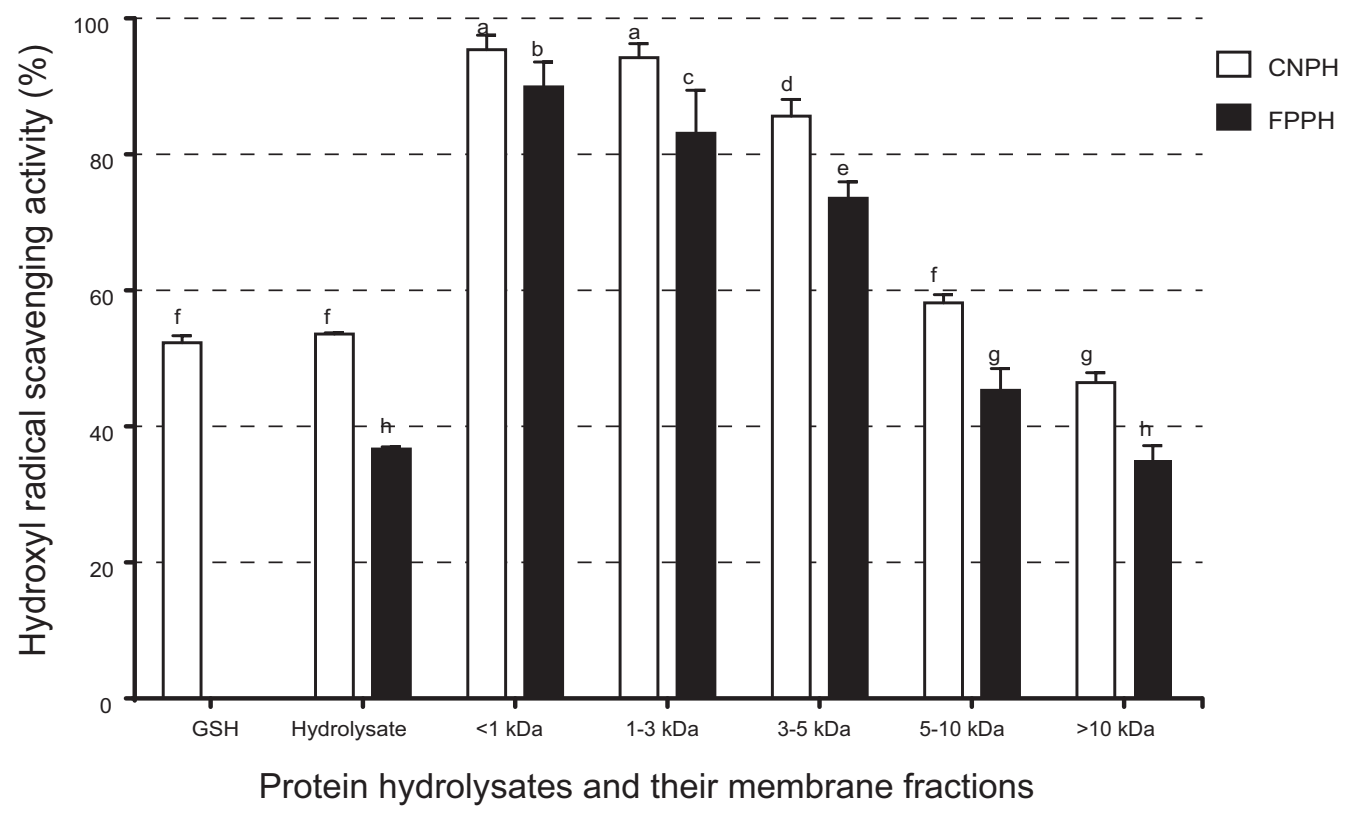

FIGURE 2. Hydroxyl radical scavenging activity of pepsin-produced (3:100 ratio E/S) cashew nut (CNPH) and Alcalase-produced (2:100 ratio E/S) fluted-pumpkin (FPPH) protein hydrolysates and their membrane fractions. Columns with the different letters have mean values that are significantly different at $\mathrm{p}<0.05$. 


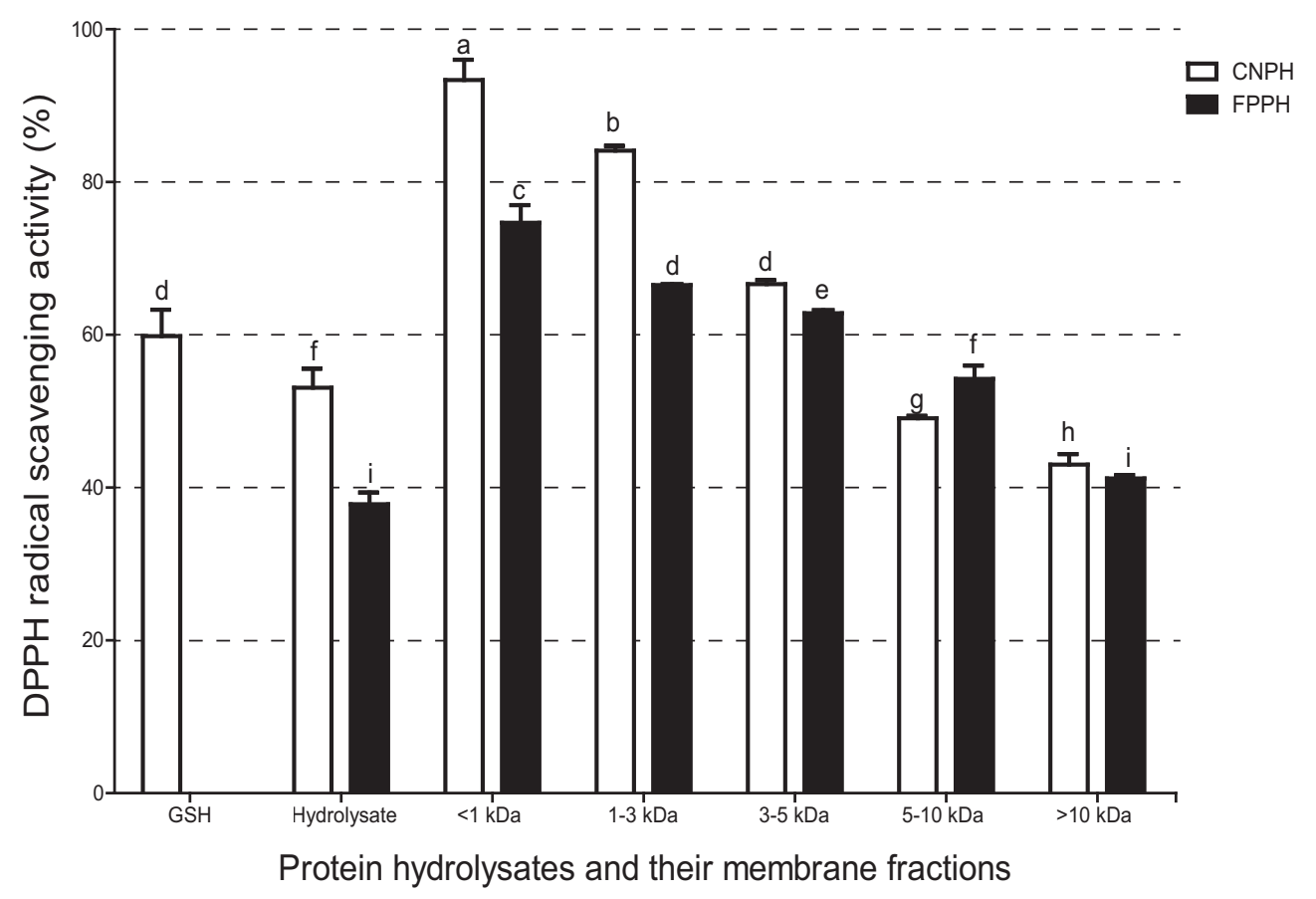

FIGURE 3. DPPH radical scavenging activity pepsin-produced (3:100 ratio E/S) of cashew (CNPH) and Alcalase-produced (2:100 ratio E/S) fluted-pumpkin protein hydrolysates and their membrane fractions. Columns with different letters have mean values that are significantly different at $\mathrm{p}<0.05$.

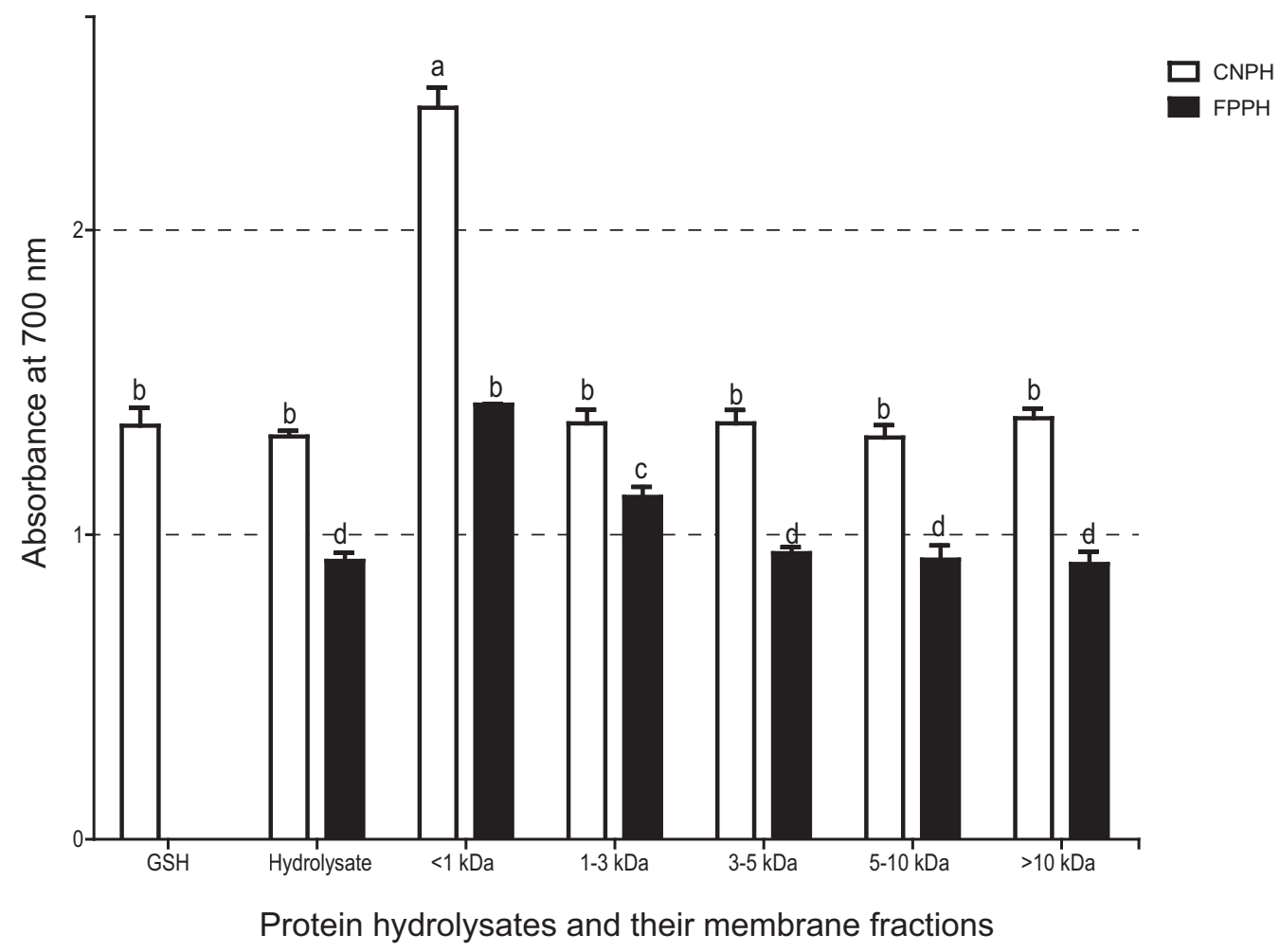

FIGURE 4. Ferric reducing power of pepsin-produced (3:100 ratio E/S) cashew nut (CNPH) and Alcalase-produced (2:100 ratio E/S) fluted-pumpkin (FPPH) protein hydrolysates and their membrane fractions. Columns with the different letters have mean values that are significantly different at $\mathrm{p}<0.05$. 
tion of $<1 \mathrm{kDa}$ fraction, exhibited similar absorbance value ( 1.4) compared to GSH (depicting same reducing power ability) whereas, the reducing powers of the membrane fractions from FPPH decreased at an increased molecular sizes (Figure 4). The current observation contradicts the previous study [Girgih et al., 2011] that reported an increase in reducing power of the hemp protein hydrolysate fractions at increased peptide sizes. The ferric reducing power of the pepsin-produced (3:100 ratio $\mathrm{E} / \mathrm{S}) \mathrm{CNPH}$ and its fractions (1.45-2.47) was higher than those of Alcalase-produced (2:100 ratio E/S) FPPH and its membrane fractions (1.00$1.46)$, with better reducing ability (2.47 and 1.46) from their respective $<1 \mathrm{kDa}$ fractions. The differences in the reducing power exhibited by CNPH and FPPH may be related to the increased availability of hydrogen ions [Kong \& Xiong, 2006] produced during CNPI hydrolysis. Notably, the presence of reducing compounds caused reduction of $\mathrm{Fe}^{3+}$ / ferricyanide complex to ferrous $\left(\mathrm{Fe}^{2+}\right)$ through electron donation [Jemil et al., 2017], thereby increasing the absorbance of the reaction. This is exemplified by the higher cysteine content of the $<1 \mathrm{kDa}$ peptides, which also displayed the highest absorbance value. The results are consistent with previous finding that sulfur-containing amino acids enhance ferric reducing power properties of food protein hydrolysates [Udenigwe \& Aluko, 2011].

The current study further supported the findings from a previous study on African yam bean seed protein hydro- lysate [Ajibola et al., 2013] that the highest reducing power values did not correspond to the higher HAA contents. For instance, the highest reducing power (2.47 and 1.46) but lowest HAA (26.06 and 29.32\%) values were obtained for the $<1 \mathrm{kDa}$ fractions compared to the lowest reducing power (1.45 and 1.00) but highest HAA (35.46-33.15\%) values of $3-5 \mathrm{kDa}$ fractions from CNPH and FPPH, respectively as evident in Figure 4 and Table 1. However, the previous study of Pownall et al. [2010] on the dependence of reducing power of pea seed protein hydrolysate fractions on its total HAA contents rather than their peptide sizes is different from present findings.

\section{Ferrous ion chelating activity}

Active metals have been suggested to be involved in several key pathogenic processes exhibited in cardio- and/or neurodegenerative diseases in the biological system [Mundi \& Aluko, 2014]. For instance, the reaction between redoxactive ferrous ion $\left(\mathrm{Fe}^{2+}\right)$ and $\mathrm{H}_{2} \mathrm{O}_{2}$ can generate ${ }^{\circ} \mathrm{OH}$, which has been implicated in various oxidant-induced metabolic disorders [Aderinola et al., 2018]. Therefore, employing chelating agents such as CNPH and FPPH to inactivate ferrous ions and prevent formation of nontoxic metal complexes could play an important role in preventing oxidative injuries in the body. The results show no effect of peptide size on ferrous ion chelation ability of the samples (Figure 5). However, fractionation of the CNPH led to improved fer-

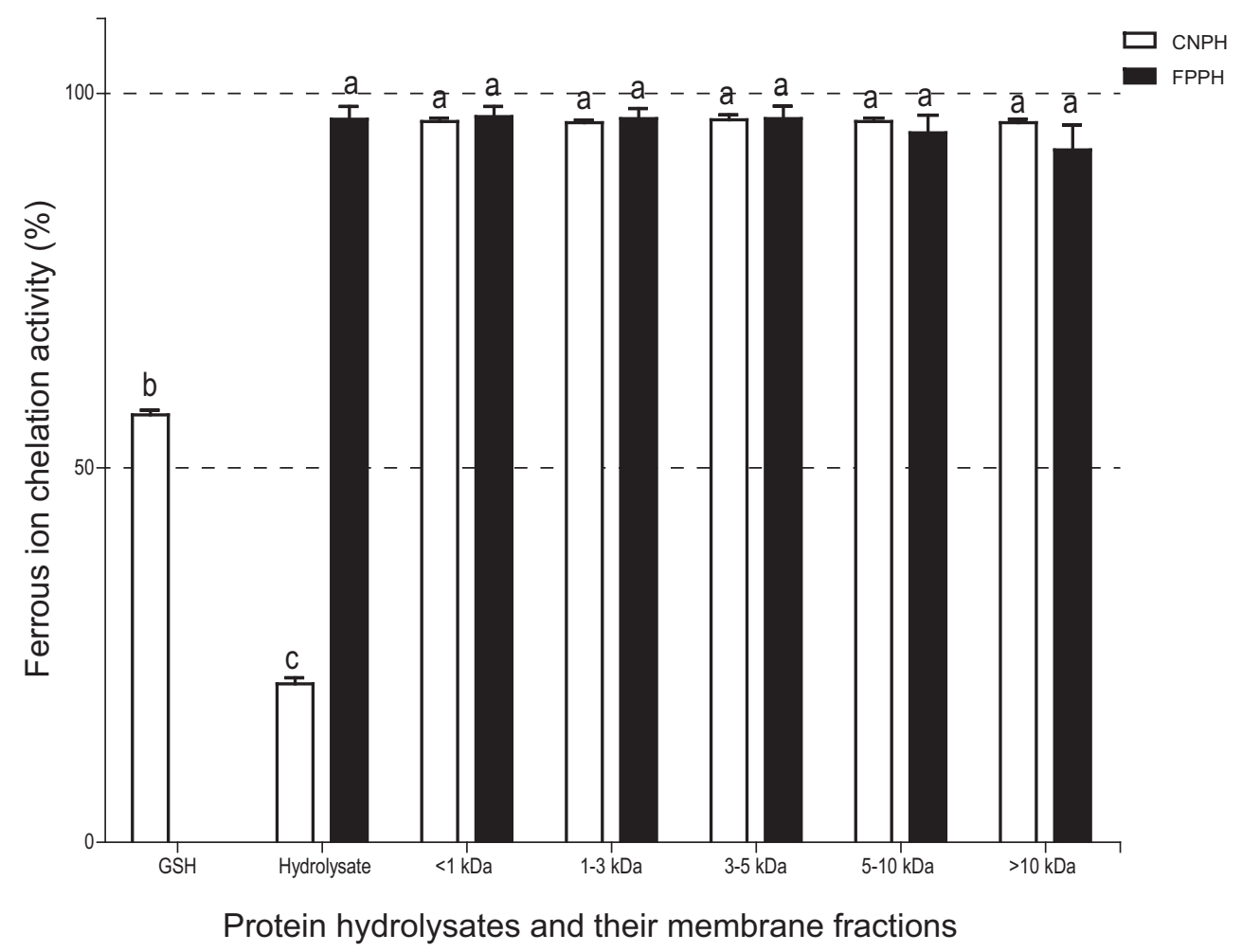

FIGURE 5. Ferrous ion chelation activity of pepsin-produced (3:100 ratio E/S) cashew nut and Alcalase-produced (2:100 ratio E/S) fluted-pumpkin $(\mathrm{FPPH})$ protein hydrolysates and their membrane fractions. Columns with the different letters have mean values that are significantly different at $\mathrm{p}<0.05$. 
rous ion chelation, which suggests stronger synergistic effects for the peptide fractions. The results obtained in this work show stronger ferrous ion chelation for the peptide fractions when compared to the 15.7-38.5\% values (also at $1 \mathrm{mg} / \mathrm{mL}$ ) reported for similar hemp seed peptides peptides [Girgih et al., 2011]. The differences may be due to variations in the type of protein substrates and proteolytic enzymes used for each work.

The degree of protein hydrolysis and type of amino acid have been shown to alter ferrous ion chelation activity of isolated peptides [Jamdar et al., 2010]. However, the present study is contradictory to the previous report of Jamdar et al. [2010] because even though the CNPH had a higher DH, the metal chelating ability was lower than that of FPPH. Moreover, there were no significant $(\mathrm{p}>0.05)$ differences between the ferrous ion chelation ability of all the peptide fractions.

\section{In vitro activities against the renin-angiotensin converting enzymes system}

The CNPI and FPPI were each subjected to enzymatic hydrolysis using Alcalase or pepsin at different concentrations (E/S ratio of 1-4:100) and the hydrolysates evaluated for $\mathrm{ACE}$ and renin inhibitions. As shown in Figure 6, the ACE-inhibitory activity of pepsin-CNPH samples was mostly better than the Alcalase-CNPH. In contrast, ACE-inhibitory activity of Alcalase-FPPH was similar to those obtained pepsin-FPPH, except that the 4:100 E/S pepsin-FPPH was significantly lower. The results indicate that intrinsic differences in the primary structure of the proteins may have led to the production of peptides with different amino acid sequences and hence the observed variations in ACE-inhibitory activity of CNPH and FPPH.

The CNPI was hydrolyzed using 3:100 (E/S) pepsin for $2 \mathrm{~h}$, and the hydrolysate passed through membranes of different sizes, and was then tested for ACE-inhibitory activity. The results show that membrane separation did not improve the ACE-inhibitory activity of the CNPH (Figure 7). This is because there were no significant differences $(\mathrm{p}>0.05)$ between the CNPH and the $<1,1-3$, $3-5$ and $5-10 \mathrm{kDa}$ peptide fractions. However, ACE-inhibitory activity was significantly $(\mathrm{p}<0.05)$ less for $>10 \mathrm{kDa}$ peptides when compared to CNPH. The results (Figure 7) are consistent with previous reports [Montone et al., 2019; Ratnayani et al., 2019] that have showed higher ACE-inhibitory potency of low molecular weight peptides when compared to peptides of bigger sizes.

The FPPI was hydrolyzed with 2:100 (E/S) Alcalase for $4 \mathrm{~h}$ and the hydrolysate also passed through membranes of different sizes. As shown in Figure 7, membrane fractionation led to decreased potency of the FPPH peptides against ACE, except $1-3 \mathrm{kDa}$ peptides. Moreover, the smaller-size peptides $(<5 \mathrm{kDa})$ exhibited significantly $(\mathrm{p}<0.05)$ stronger ACE inhibition than the bigger $(>5 \mathrm{kDa})$ peptides. The results suggest that a strong peptide synergy exists within the protein hydrolysates (pepsin-CNPH and Alcalase-FPPH), which favored a high rate of ACE inhibition. Membrane separation reduced this peptide synergy and hence most of the peptide fractions exhibited weaker ACE inhibition than their respective hydro- lysates. Similar findings of reduced peptide potency against ACE as a result of membrane ultrafiltration have also been reported [da Cruz et al., 2016]. Results from a previous study support the current observations about the direct dependency of peptide bioactivities on their amino acids content. For instance, highly acidic amino acids (Asp and Glu) led to a net negative charged peptide with improve antioxidant and effective ACE inhibitory action [Nourmohammadi et al., 2017]. This was attributed to chelation of the zinc atoms in the active center of ACE, which reduced catalytic activity. Similarly, the presence of aromatic and hydrophobic amino acids has been shown to contribute to potency of ACE-inhibitory peptides [Wu et al., 2006a].

In contrast to the ACE inhibition results, Figure 8 shows that the maximum renin inhibition was achieved using 2:100 (E/S) Alcalase $(63 \%)$ and 4:100 (E/S) pepsin (48\%) to prepare CNPH and FPPH, respectively. The present findings showing lower renin-inhibitory activity of the hydrolysates when compared to ACE-inhibitory activity are similar to previous reports on canola [Alashi et al., 2014] but contrary to these on hemp [Malomo et al., 2015] protein hydrolysates. For the CNPH, the results suggest that initial increase in Alcalase concentration from 1-2:100 (E/S) promoted the production of peptides with structural features that enhanced renin inhibition. However, further increases in Alcalase concentration may have led to hydrolysis and structural inactivation of the active peptides, hence the reductions in renin-inhibitory activity at enzyme levels $>2: 100(\mathrm{E} / \mathrm{S})$. The opposite effect was obtained for the FPPH whereby the highest renin inhibition was obtained at 4:100 (E/S) pepsin. Therefore, it is possible that at 1-3:100 (E/S) pepsin, the level of FPPI proteolysis was not sufficient to produce strong renin-inhibitory peptides when compared to the $4: 100(\mathrm{E} / \mathrm{S})$ pepsin. Differences in enzyme specificity (peptide cleavage points) may have contributed to the varied outcome between Alcalase and pepsin digestions. After subjecting the two hydrolysates to membrane filtration process, the renin inhibition activities of their membrane fractions were significantly $(p<0.05)$ improved as evident in results presented in Figure 9. However, there were no significant differences between the renin-inhibitory activities of the CNPH peptide fractions. In contrast, the 5-10 kDa FPPH peptide fraction exhibited significantly $(\mathrm{p}<0.05)$ higher renin-inhibitory activity when compared to the other fractions. The results suggest that for the renin inhibition, peptide composition may be more important than peptide size for the FPPH.

Differences in catalytic mechanisms between ACE and renin might have also contributed to the different results observed for CNPH and FPPH inhibitory activities. For instance, the pepsin-produced $\mathrm{CNPH}$ and Alcalase-produced FPPH had higher ACE (Figures 6 and 7) but lower renin (Figures 8 and 9), thus revealing the two peptides to have higher affinity for ACE than renin. A previous study [Olagunju et al., 2018] had attributed the low inhibition of renin activity to reduced accessibility to inhibitors as a result of its (renin) more folded protein conformation, which contrasts the more open conformation and easier accessibility of ACE to potential inhibitors. 


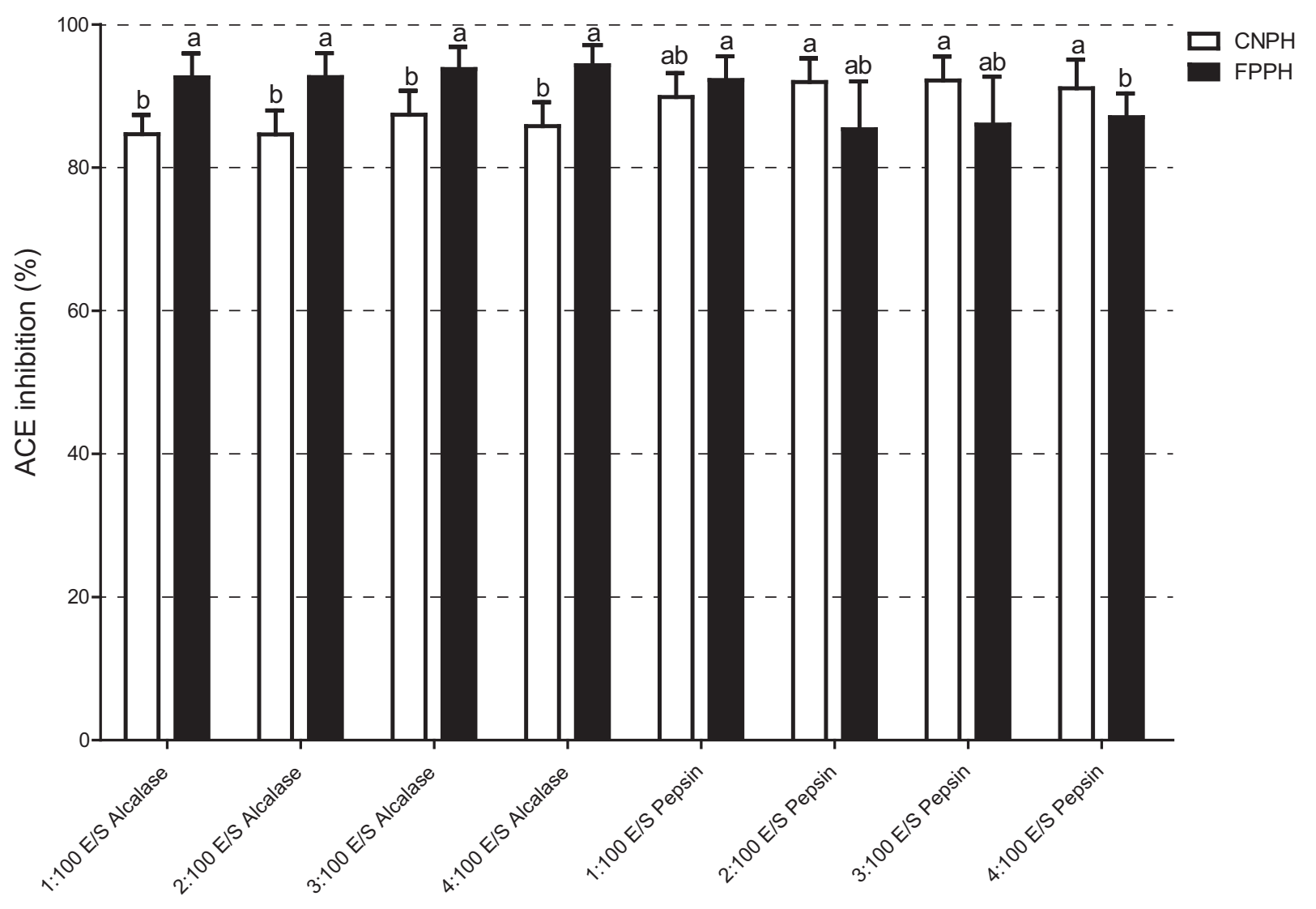

Concentrations of proteases used for hydrolysis

FIGURE 6. ACE inhibition properties of cashew nut (CNPH) and fluted-pumpkin (FPPH) protein hydrolysates produced at different protease concentrations (1-4:100 ratio E/S). Columns with the different letters have mean values that are significantly different at $p<0.05$.

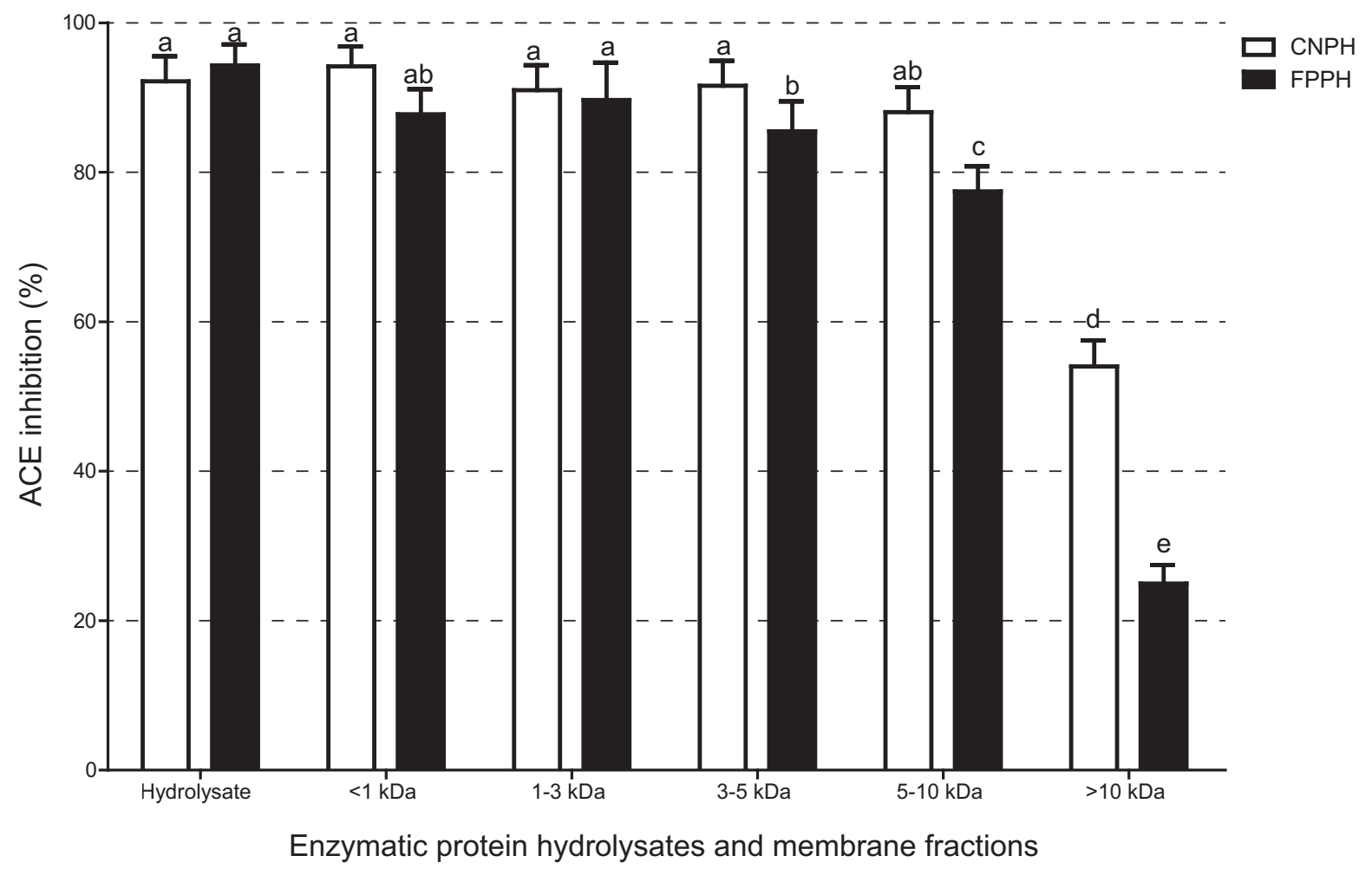

FIGURE 7. ACE inhibition properties of pepsin-produced (3:100 ratio E/S) cashew nut (CNPH) and Alcalase-produced (2:100 ratio E/S) fluted-pumpkin $(\mathrm{FPPH})$ protein hydrolysates and their membrane fractions. Columns with the different letters have mean values that are significantly different at $\mathrm{p}<0.05$. 


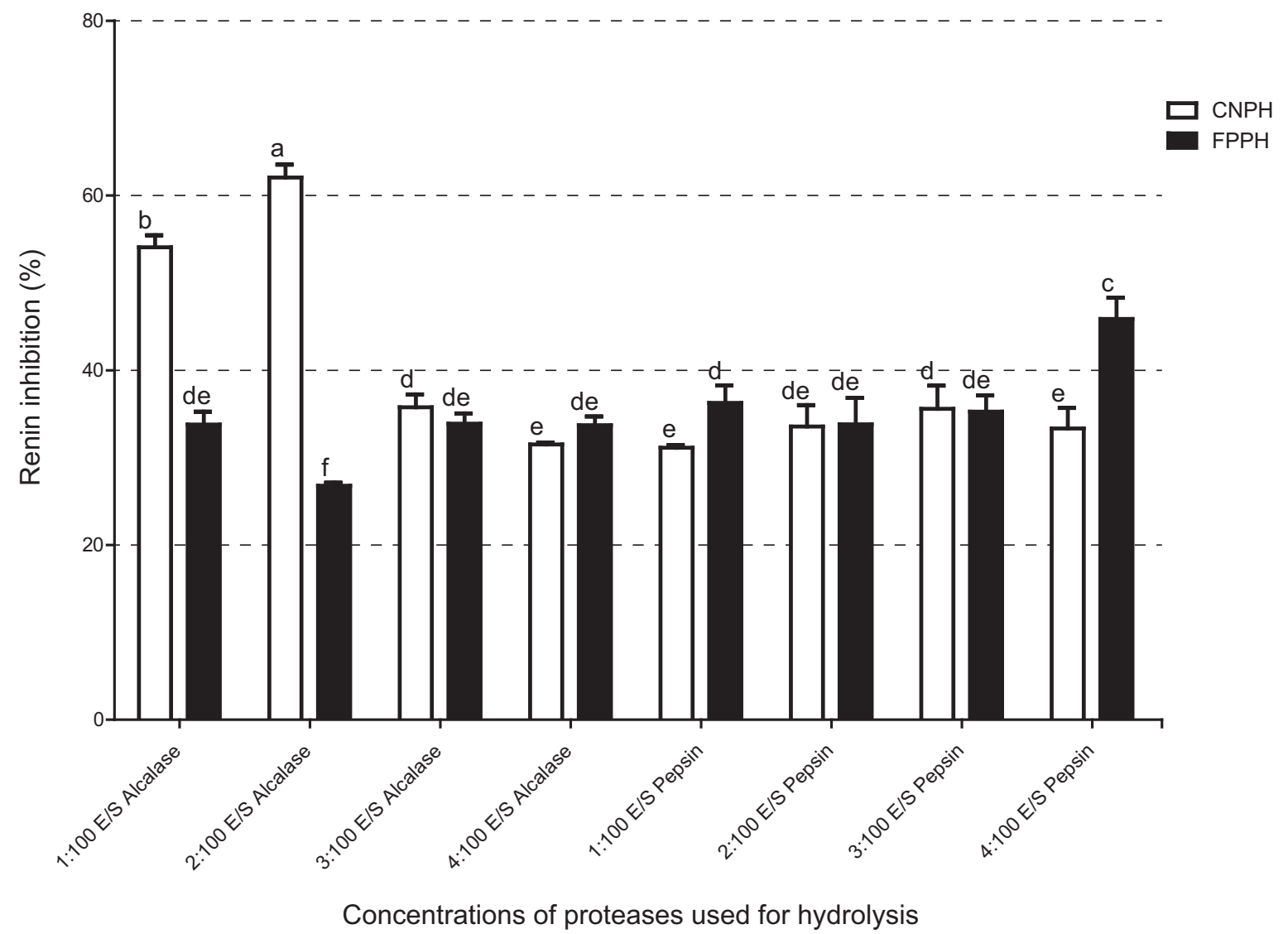

FIGURE 8. Renin inhibition properties of cashew nut (CNPH) and fluted-pumpkin (FPPH) protein hydrolysates produced at different protease concentrations (1-4:100 ratio E/S). Columns with the different letters have mean values that are significantly different at $\mathrm{p}<0.05$.

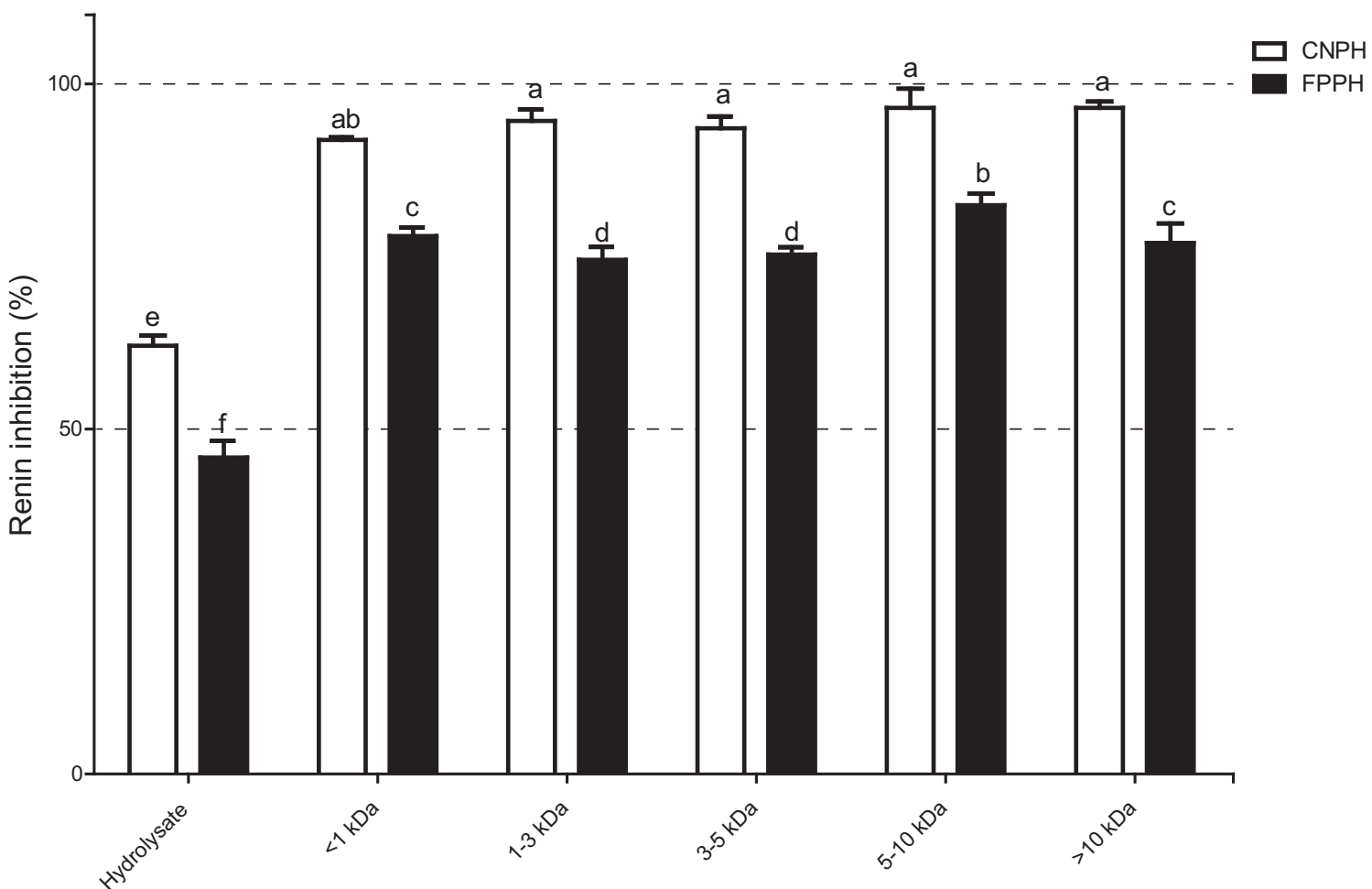

Enzymatic protein hydrolysates and membrane fractions

FIGURE 9. Renin inhibition properties of pepsin-produced (3:100 ratio E/S) cashew nut (CNPH) and Alcalase-produced (2:100 ratio E/S) fluted-pumpkin $(\mathrm{FPPH})$ protein hydrolysates and their membrane fractions. Columns with the different letters have mean values that are significantly different at $\mathrm{p}<0.05$. 


\section{CONCLUSIONS}

The protease-hydrolysis of CNPI and FPPI yielded peptides with in vitro antioxidant and RAS-inhibitory activities, which provides new peptide tools for nutritional improvement of human health. Both CNPH and FPPH contain LMW peptides with potentially fast absorption in the gastrointestinal tract. The strongest scavenging of hydroxyl and $\mathrm{DPPH}^{*}$ radicals as well as ferric ion reducing capacity were obtained for the $<1 \mathrm{kDa}$ peptide fraction. Stronger ACE inhibition by $<1 \mathrm{kDa}$ peptides when compared to bigger peptides was observed only when the CNPI was hydrolyzed by pepsin for $2 \mathrm{~h}$. In contrast, CNPI hydrolysis by pepsin for $2 \mathrm{~h}$ yielded $<1 \mathrm{kDa}$ peptides with weaker renin inhibitory activity than the bigger peptides. Thus, the potency of peptide fractions may be dependent not only on the type of protease but the length of released peptides. Overall, the strong ACE and renin inhibitions suggest that these protein hydrolysates could be used as suitable ingredients for the formulation of health-promoting functional foods and nutraceuticals.

\section{CONFLICT OF INTEREST}

The authors declare that they do not have any conflict of interest.

\section{RESEARCH FUNDING}

We acknowledge support of the Natural Sciences and Engineering Council of Canada (NSERC), funding reference number RGPIN 2018-06019. Cette recherche a été financée par le Conseil de recherches en sciences naturelles et en génie du Canada (CRSNG), numéro de référence RGPIN 2018-06019.

\section{REFERENCES}

1. Aderinola, T.A., Fagbemi, T.N., Enujiugha, V.N., Alashi, A.M., Aluko, R.E. (2019). In vitro antihypertensive and antioxidative properties of trypsin-derived Moringa oleifera seed globulin hydrolyzate and its membrane fractions. Food Science and Nutrition, 7(1), 132-138.

2. Aderinola, T.A., Fagbemi, T.N., Enujiugha, V.N., Alashi, A.M., Aluko, R.E. (2018). Amino acid composition and antioxidant properties of Moringa oleifera seed protein isolate and enzymatic hydrolysates. Heliyon, 4(10), art. no. e00877.

3. Adler-Nissen, J. (1979). Determination of the degree of hydrolysis of food protein hydrolysates by trinitrobenzenesulfonic acid. Journal of Agricultural and Food Chemistry, 27(6), 1256-1262.

4. Ajibola, C.F., Malomo, S.A., Fagbemi, T.N., Aluko, R.E. (2016). Polypeptide composition and functional properties of African yam bean seed (Sphenostylis sternocarpa) albumin, globulin and protein concentrate. Food Hydrocolloids, 56, 189- 200.

5. Ajibola, C.F., Fashakin, J.B., Fagbemi, T.N., Aluko, R.E. (2013). Renin and angiotensin converting enzyme inhibition with antioxidant properties of African yam bean protein hydrolysate and reverse-phase HPLC separated peptide fractions. Food Research International, 52(2), 437-444.

6. Alashi, A.M., Blanchard, C.L., Mailer, R.J., Agboola, S.O., Mawson, A.J., He, R., Malomo, S.A., Girgih, A.T., Aluko, R.E.
(2014). Blood pressure lowering effects of Australian canola protein hydrolysates in spontaneously hypertensive rats. Food Research International, 55, 281-287.

7. Aluko R.E. (2019a). Food protein-derived renin-inhibitory peptides: in vitro and in vivo properties. Journal of Food Biochemistry. 43(1), art. no. e12648.

8. Aluko, R.E. (2019b). Antihypertensive foods: Protein hydrolysates and peptides. In: L. Melton, F. Shahidi, P. Varelis (Eds.), Encyclopedia of Food Chemistry. Elsevier: Oxford, 3, pp. 237-247.

9. Aluko, R.E., Monu, E. (2003). Functional and bioactive properties of quinoa seed protein hydrolysates. Journal of Food Science, 68(4), 1254-1258.

10. Arise, R.O., Acho, M.A., Yekeen, A.A., Omokanye, I.A., Sunday-Nwaso, E.O., Akiode, O.S., Malomo, S.O. (2019). Kinetics of angiotensin-1 converting enzyme inhibition and antioxidative properties of Azadirachta indica seed protein hydrolysates. Heliyon, 5(5), art. no. e01747.

11. Arise, A.K., Alashi, A.M., Nwachukwu, I.D., Malomo, S.A., Aluko, R.E., Amonsou, E. (2017). Inhibitory properties of bambara protein hydrolysate and its membrane fractions against angiotensin converting enzymes, renin and free radicals. Journal of Science, Food \& Agriculture, 97(9), 2834-2841.

12. Bhaskar, B., Laxmi Ananthanarayan, L., Jamdar, S.N. (2019). Effect of enzymatic hydrolysis on the functional, antioxidant, and angiotensin I-converting enzyme (ACE) inhibitory properties of whole horse gram flour. Food Science and Biotechnology, 28(1), 43-52.

13. Bidlingmeyer, B.A., Cohen, S.A., Tarvin, T.L. (1984). Rapid analysis of amino acids using pre-column derivatization. Journal of Chromatography B: Biomedical Sciences and Applications, 336(1), 93-104.

14. da Cruz, J.N., Pimenta, D.C., De Melo, R.L., Nascimento, J.R.O. (2016). Isolation and biochemical characterisation of angiotensin-converting enzyme inhibitory peptides derived from the enzymatic hydrolysis of cupuassu seed protein isolate. Journal of Functional Foods, 27, 104-114.

15. Erdmann, K., Cheung, B.W., Schröder, H. (2008). The possible roles of food-derived bioactive peptides in reducing the risk of cardiovascular disease. Journal of Nutritional Biochemistry, 19(10), 643-654.

16. Fagbemi, T.N. (2009). Effect of processing on chemical composition of cashew nut (Anacardium occidentale). Journal of Food Science and Technology - Mysore, 46(1), 36-40.

17. Fagbemi, T.N. (2007). Effects of processing on the nutritional composition of fluted pumpkin (Telfairia occidentalis) seed flour. Nigerian Food Journal, 25(1), doi: 10.4314/nifoj.v25i1.33650.

18. Gehrke, C.W., Wall, L.L., Absheer, J.S., Kaiser, F.E., Zumwalt, R.W. (1985). Sample preparation for chromatography of amino acids: acid hydrolysis of proteins. Journal of Association of Official Analytical Chemists, 68(5), 811-821.

19. Girgih, A.T., Onuh, J.O., Nwachukwu, I.D., Malomo, S.A., Aluko, R.E. (2016). Antihypertensive properties of pea protein hydrolysate during short and long term oral administration to spontaneously hypertensive rats. Journal of Food Science, 81 (5), H1281-1287.

20. Girgih, A.T., Udenigwe, C.C., Aluko, R.E. (2011). In vitro antioxidant properties of hemp seed (Cannabis sativa L.) protein hydrolysate fractions. Journal of American Oil Chemists' Society, 88(3), 381-389. 
21. Ijarotimi, S.O., Malomo, S.A., Fagbemi, T.N., Osundahunsi, O.F., Aluko, R.E. (2018a). Structural and functional properties of Buccholzia coriacea seed flour and protein concentrate at different $\mathrm{pH}$ and protein concentrations. Food Hydrocolloids, 74, 275-288.

22. Ijarotimi, O.S., Malomo, S.A., Alashi, A.M., Nwachukwu, I.D., Fagbemi, T.N., Osundahunsi, O.F., Aluko, R.E. (2018b). Antioxidant and antihypertensive activities of wonderful cola (Buchholzia coriacea) seed protein and enzymatic protein hydrolysates. Journal of Food Bioactives, 3, 133-143.

23. Jakubczyk, A., Baraniak, B. (2014). Angiotensin I Converting Enzyme inhibitory peptides obtained after in vitro hydrolysis of pea (Pisum sativum var. Bajka) globulins. BioMed Research International, 2014, art. no. 438459.

24. Jamdar, S.N., Rajalakshmi, V., Pednekar, M.D., Juan, F., Yardi, V., Sharma, A. (2010). Influence of degree of hydrolysis on functional properties, antioxidant activity and ACE inhibitory activity of peanut protein hydrolysate. Food Chemistry, 121 (1), 178-184.

25. Jemil, I., Abdelhedi, O., Nasri, R., Mora, L., Jridi, M., Aristoy, M.C., Toldrá, F., Nasri, M. (2017). Novel bioactive peptides from enzymatic hydrolysate of Sardinelle (Sardinellaaurita) muscle proteins hydrolysed by Bacillus subtilis A26 proteases. Food Research International, 100, 121-133.

26. Jin, D.X., Liu, X.L., Zheng, X.Q., Wang, X.J., He, J.F. (2016). Preparation of antioxidative corn protein hydrolysates, purification and evaluation of three novel corn antioxidant peptides. Food Chemistry, 204, 427-436.

27. Ketnawa, S., Benjakul, S., Martínez-Alvarez, O., Rawdkuen, S. (2017). Fish skin gelatinhydrolysates produced by visceral peptidase and bovine trypsin: Bioactivity and stability. Food Chemistry, 215, 383-390.

28. Kong, B.H., Xiong, Y.L. (2006). Antioxidant activity of zein hydrolysates in aliposome system and the possible mode of action. Journal of Agricultural and Food Chemistry, 54(16), 6059-6068.

29. Landry, J., Delhaye, S. (1992). Simplified procedure for the determination of tryptophan of foods and feedstuffs from barytic hydrolysis. Journal of Agricultural and Food Chemistry, 40(5), 776-779.

30. Li, P., Jia, J., Fang, M., Zhang, L., Guo, M., Xie, J., Xia, Y., Zhou, L., Wei, D. (2014). In vitro and in vivo ACE inhibitory of pistachio hydrolysates and in silico mechanism of identified peptide binding with ACE. Process Biochemistry, 49(5), 898-904.

31. Liu, C., Peng, Q., Zhong, J., Liu, W., Zhong, Y., Wang, F. (2018). Molecular and functional properties of protein fractions and isolate from cashew nut (Anacardium occidentale L.). Molecules, 23(2), 393-408.

32. Magana, M.D., Segura-Campos, M., Davila-Ortiz, G., Betancur-Ancona, D., Chel-Guerrero, L. (2015). ACE-I inhibitory properties of hydrolysates from germinated and ungerminated Phaseolus lunatus proteins. Food Science and Technology (Campinas), 35(1), 167-174.

33. Malomo, S.A., Aluko, R.E. (2015). A comparative study of the structural and functional properties of isolated hemp seed (Cannabis sativa L.) albumin and globulin fractions. Food Hydrocolloids, 43, 743-752.

34. Malomo, S.A., Onuh, J.O., Girgih, A.T., Aluko, R.E. (2015). Structural and antihypertensive properties of enzymatic hemp seed protein hydrolysates. Nutrients, 7(9), 7616-7632.
35. Malomo, S.A., He, R., Aluko, R.E. (2014). Structural and functional properties of hemp seed protein products. Journal of Food Science, 79(8), C1512-1521.

36. Majumder, K., Wu, J. (2015). Molecular targets of antihypertensive peptides: Understanding the mechanisms of action based on the pathophysiology of hypertension. International Journal of Molecular Sciences, 16(1), 256-283.

37. Markwell, M.A.K., Haas, S.M., Bieber, L.L., Tolbert, N.E. (1978). Modification of lowry procedure to simplify protein determination in membrane and lipoprotein samples. Analytical Biochemistry, 87(1), 206-210.

38. Montone, C.M., Chiozzi, R.Z., Marchetti, N., Cerrato, A., Antonelli, M., Capriotti, A. L., Cavaliere, C., Piovesana, S., Laganà, A. (2019). Peptidomic approach for the identification of peptides with potential antioxidant and antihypertensive effects derived from Asparagus by-products. Molecules, 24(19), art. no. 3627.

39. Mundi, S., Aluko, R.E. (2014). Inhibitory properties of kidney bean protein hydrolysate and its membrane fractions against renin, angiotensin converting enzyme, and free radicals. Austin Journal of Nutrition and Food Science, 2(1), art. no. 1008.

40. Nourmohammadi, E., SadeghiMahoonak, A., Alami, M., Ghorbani, M. (2017). Amino acid composition and antioxidative properties of hydrolysed pumpkin (Cucurbita pepo L.) oil cake protein. International Journal of Food Properties, 20(12), 3244-3255.

41. Nwachukwu, I., Alashi, A.M., Zahradka, P., Aluko, R.E. (2019). Transport, bioavailability, safety and calmodulin-dependent phosphodiesterase-inhibitory properties of flaxseed-derived bioactive peptides. Journal of Agricultural and Food Chemistry, 67(5), $1429-1436$.

42. Olagunju, A.I., Omoba, O.S., Enujiugha, V.N., Alashi, A.M., Aluko, R.E. (2018). Antioxidant properties, ACE/renin inhibitory activities of pigeon pea hydrolysates and effects on systolic blood pressure of spontaneously hypertensive rats. Food Science and Nutrition, 6(7), 1879-1889.

43. Pownall, T.L., Udenigwe, C.C., Aluko, R.E. (2010). Amino acid composition and antioxidant properties of pea seed (Pisum sativum L.) enzymatic protein hydrolysate fractions. Journal of Agricultural and Food Chemistry, 58(8), 4712-4718.

44. Ralison, S.S., Tounkara, F., Karangwa, E., Yong, H.S., Le, G. (2013). In vitro antioxidant activities of protein hydrolysate from germinated black soybean (Glycine max L.). Advance Journal of Food Science and Technology, 5(4), 453-459.

45. Ratnayani, K., Suter, I.K., Antara, N.S., Putra, I.N.K. (2019). Effect of in vitro gastrointestinal digestion on the Angiotensin Converting Enzyme (ACE) inhibitory activity of pigeon pea protein isolate. International Food Research Journal, 26(4), 1397-1404.

46. Siddeeg, A., Xu, Y., Jiang, Q., Xia, W. (2015). In vitro antioxidant activity of protein fractions extracted from seinat (Cucumis melo var. tibish) seeds. CyTA - Journal of Food, 13(3), 472-481.

47. Siow, H.L., Gan, C.Y. (2013). Extraction of antioxidative and antihypertensive bioactive peptides from Parkia speciosa seeds. Food Chemistry, 141 (4), 3435-3442.

48. Thammarat, K., Leena, N., Punnanee, S., Soottawat, B. (2015). Functional and antioxidative properties of Bambara groundnut (Voandzeia subterranea) protein hydrolysates. International Food Research Journal, 22(4), 1584-1595. 
49. Udenigwe, C.C., Aluko, R.E. (2011). Chemometric analysis of the amino acid requirements of antioxidant food protein hydrolysates. International Journal of Molecular Sciences, 12(5), 3148-3161.

50. Udenigwe, C.C., Li, H., Aluko, R.E. (2012). Quantitative structure-activity relationship modeling of renin-inhibiting dipeptides. Amino Acids, 42(4), 1379-1386.

51. Udenigwe, C.C., Girgih, A.T., Mohan, A., Gong, M., Malomo, S.A., Aluko, RE. (2017). Antihypertensive and bovine plasma oxidation-inhibitory activities of spent hen meat protein hydrolysates. Journal of Food Biochemistry, 41 (4), art no. e12378.

52. Wu, J., Aluko, R.E. Nakai, S. (2006a). Structural requirements of angiotensin I-converting enzyme inhibitory peptides: quantitative structure-activity relationship study of di- and tri-peptides. Journal of Agricultural and Food Chemistry, 54(3), 732-738.

53. Wu, J., Aluko, R.E., Nakai, S. (2006b). Structural requirements of Angiotensin I-Converting Enzyme inhibitory peptides: Quantitative structure-activity relationship modeling of peptides con- taining 4-10 amino acid residues. QSAR and Combinatorial Science, 25(10), 873-880.

54. Xie, Z., Huang, J., Xu, X., Jin, Z. (2008). Antioxidant activity of peptides isolated from alfalfa leaf protein hydrolysate. Food Chemistry, 111 (2), 370-376.

55. Xia, Y., Bamdad, F., Gänzle, M., Chen, L. (2012). Fractionation and characterization of antioxidant peptides derived from barley glutelin by enzymatic hydrolysis. Food Chemistry, 134(3), 1509-1518.

56. Zhang, S.B., Wang, Z., Xu, S.Y. (2008). Antioxidant and antithrombotic activities of rapeseed peptides. Journal of the American Oil Chemists' Society, 85(6), 521-527.

57. Zhuang, H., Tang, N., Yuan, Y. (2013). Purification and identification of antioxidant peptides from corn gluten meal. Journal of Functional Foods, 5(4), 1810-1821.

Submitted: 14 January 2020. Revised: 4 March and 7 May 2020. Accepted: 14 May 2020. Published on-line: 19 June 2020. 
